\title{
EQUIVALENT MODELS FOR PHOTOVOLTAIC CELL - A REVIEW
}

\author{
N. M. F. T. S. Araújoa , ABSTRACT \\ F. J. P. Sousab, \\ and F. B. Costa ${ }^{b}$ \\ ${ }^{a}$ Universidade Federal do Rio Grande do Norte \\ Departamento de Engenharia Mecânica \\ Bairro Lagoa Nova, CP 59.078-970 \\ Natal, Rio Grande do Norte, Brasil \\ nicolas.araujo@ufersa.edu.br \\ ${ }^{\mathrm{b}}$ Universidade Federal do Rio Grande do Norte \\ Escola de Ciências e Tecnologia \\ Bairro Lagoa Nova, CP 59.078-970 \\ Natal, Rio Grande do Norte, Brasil \\ flaviocosta@ect.ufrn.br, \\ fabio.sousa@ect.ufrn.br \\ Over the years, the contribution of photovoltaic energy to an eco-friendly \\ world is continually increasing. Photovoltaic (PV) cells are commonly \\ modelled as circuits, so finding the appropriate circuit model parameters of \\ PV cells is crucial for performance evaluation, control, efficiency \\ computations and maximum power point tracking of solar PV systems. The \\ problem of finding circuit model of solar PV cells is referred to as "PV cell \\ equivalent model problem". In this paper, the existing research works on PV \\ cell model parameter estimation problem are classified according to error \\ quali-quantitative analysis, number of parameters, translation equations and \\ PV technology. The existent models were discussed pointing out its different \\ levels of approximation. A qualitative comparative ranking was made and \\ four models were found to be the best ones for simulating PV cells. Besides, \\ based on the conducted review, some recommendations for future research \\ are provided. \\ Received: Aug 23, 2020 \\ Revised: Nov 30, 2020 \\ Accepted: Dec 18, 2020 \\ Keywords: solar energy; equivalent model; ranking; solar photovoltaic
}

\section{NOMENCLATURE}

$a$ ideality factor

$E_{g}$ band gap (eV)

$E_{g, r e f}$ band gap at STC $(\mathrm{eV})$

$F F$ fill factor

$G \quad$ solar irradiation $\left(\mathrm{W} / \mathrm{m}^{2}\right)$

$G_{\text {ref }}$ reference solar irradiation $\left(=1,000 \mathrm{~W} / \mathrm{m}^{2}\right)$

I cell output current (A)

$I_{m} \quad$ maximum power current $(\mathrm{A})$ cell

$I_{D} \quad$ diode current (A)

$I_{S} \quad$ cell saturation current $(\mathrm{A})$

$I_{r s} \quad$ cell reverse saturation current $(\mathrm{A})$

$I_{s c}$ short-circuit current (A)

$I_{p v} \quad$ light-generated current (A)

$I_{p v, r e f}$ light-generated current at STC (A)

$k$ Boltzmann's constant

M air mass modifier

MPPT maximum power point tracking

$P_{m} \quad$ maximum power (W)

$q$ electron charge $(\mathrm{C})$

$R_{S} \quad$ series resistance $(\Omega)$

$R_{s 0}$ reciprocal of the slope of the I-V curve for $\left(0, V_{o c}\right)$

$(\Omega)$

$R_{s, \text { ref }}$ series resistance at STC $(\Omega)$

$R_{\text {sh }} \quad$ shunt resistance $(\Omega)$

$R_{\text {sh,ref }} \quad$ shunt resistance at $\operatorname{STC}(\Omega)$

$R_{s h 0}$ reciprocal of the slope of the $\mathrm{I}-\mathrm{V}$ curve for $\left(I_{s c}, 0\right)(\Omega)$
STC Standard Test Conditions $\left(G_{r e f}\right.$ and $\left.T_{r e f}\right)$

$T \quad$ cell temperature $(\mathrm{K})$

$T_{\text {ref }}$ reference temperature $(=298.15 \mathrm{~K})$

$V \quad$ cell output voltage $(\mathrm{V})$

$V_{m}$ maximum power voltage $(\mathrm{V})$

$V_{t}$ thermal voltage $(\mathrm{K} / \mathrm{eV})$

$V_{o c}$ open-circuit voltage $(\mathrm{V})$

\section{Greek symbols}

$\mu_{I_{S c}}$ temperature coefficient of $I_{s c}(\mathrm{~A} / \mathrm{K})$

$\mu_{V_{o c}}$ temperature coefficient of $V_{o c}(\mathrm{~V} / \mathrm{K})$

\section{Subscripts \\ D Diode \\ g electrical gap \\ int internal characteristic \\ $\mathrm{m}$ maximum power \\ pv photovoltaic \\ ref standard test conditions \\ oc open-circuit condition \\ rs reverse saturation \\ $\mathrm{s}$ series resistance \\ sc short-circuit condition \\ sh shunt resistance}

\section{INTRODUCTION}


Power demand is rising due to rapid society growth and rising lifestyle standards. This worldwide increasing energy utilization is one of the greatest challenges that the world is currently leading with, since there are both the increasing accumulation of greenhouse gases and the decreasing reserves of fossil fuels (Khan et al., 2016). As result, there is a vigorous encouragement into eco-friendly energy generation over the years, and critical environmental issues that have increased the awareness to reduce the climate change and global warming. Among the up-to-date energy scenarios, renewable energy is predicted to be a notable part of energy production in the close future (Cuce et al., 2014a). There exists a vast range of green technologies accessible for clean energy generation, and the utilization of solar energy through photovoltaic (PV) cells has emerged as an auspicious source of green energy since it is one of the most efficient, with large availability, reliable, and ecofriendly solution (Cuce et al., 2014b; Singh et al., 2016; Slimani et al., 2017) for satiating the global power demand (Cuce et al., 2015) and for dealing with fossil fuel-oriented environmental concerns (Kwak et al., 2020). PV systems are free of moving parts and present low noise level (Riffat and Cuce, 2011; Ishaque et al., 2011a), and among renewables, solar PVs provide the highest power density (Uni Manitoba, 2017). In this bias, when compared with other clean energy generation technologies, the operation and maintenance costs of such systems are considerably low (Sundareswaran et al., 2015; Bianchini et al., 2016). Nowadays, over than 100 countries around the globe are using solar PV's (Green, 2015).

Support for Research and Development, and for implementing photovoltaic technologies, are crucial aspects in accelerating the widespread adoption of photovoltaic systems. These two aspects play a key role in climate policy (Torani et al., 2016). Many countries, such as Germany, Denmark, Spain, China, Taiwan, United States, United Kingdom, Japan, Sweden and South Korea have been using different mechanisms to encourage the use of renewable energy (Sampaio and González, 2017). According to the reports, the distance between non-renewable and renewable energy resources is narrowed steadily (Cuce et al., 2017), and the task of PV technology in this bias is of significant relevance.

The mathematical modelling of PV cells is crucial for purposes of design, simulation, assessment, manage and optimisation of solar PV systems (Farivar and Asaei, 2010; Caracciolo et al., 2012; Askarzadeh and Rezazadeh, 2013; Hansen et al., 2013). Furthermore, it is also decisive for proper computations and maximum power point tracking (MPPT) of PV systems.

The equivalent circuit models are the wellknown ways for modelling PV cells (Jordehi, 2016), however, there exist other approaches for modelling PV cells. Furthermore, proper modelling of PV cells encompasses not just proper circuit model, but precise circuit model parameters (Jordehi, 2016). A challenging problem in the field of renewable energy is achieving the circuit model parameters of PV cells which is a nonlinear optimisation problem since the I$\mathrm{V}$ curve of PV cells is nonlinear. A proper parameter estimation method for PV cells should:

- Provide model parameters for datasets at different conditions (Hansen, 2015);

- Present repeatability, i.e., when it is applied to a specific condition for multiple times, similar results are achieved;

- Be robust, i.e., be stable while delivering accurate model parameters, in other words, model parameters which lead to I-V data or remarkable I-V points as close as possible to the manufacturer information and/or experimental data even with variations in entries (Jordehi, 2016);

- Low time-consuming, especially when it is applied for Maximum Power Point Tracking (MPPT) (Ram et al., 2017).

A huge deal of study has already been performed to solve "PV cell equivalent model problem", however, efforts in research are still being put to effectively solve this problem.

\section{PV cell modelling}

Different models have been developed to emulate a solar cell: implicit and explicit models, besides other approaches as follows.

The explicit models are mainly based on simple analytical expressions which enable designers to determine the key parameters of a solar cell and is simpler implemented in computer programs and require less computational effort than the implicit models since normally there are not iterative numerical calculations, but a direct (explicit) expression for the parameters of PV devices.

Even in models where accuracy is not high, - in Saloux et al. (2011), the $R_{S}$ and $R_{s h}$ of the solar cells are neglected - its results are valuable for designing the electrical circuits of an industry using PV technology. Furthermore, these models can be used to the derivation of solutions for the Maximum Power Point (MPP) and the Fill Factor (FF): some authors (Green, 1981; Araujo and Sanchez, 1982; Karmalkar and Haneefa, 2011; Das, 2011) used a few measurements as well as physical parameters of an illuminated solar cell with an explicit power law model to achieve an easy closed-form estimation of the entire I-V curve, FF and MPP. Moreover, extra effort has been done for developing a simple explicit model based on implicit models (Lun et al., 2013; Das, 2012; Pavan et al., 2014). Lumb et al. (2013) used onedimensional Hovel model; Ortiz-Conde et al. (2006), applied the Co-content function $\mathrm{CC}$ to the exact explicit analytical solutions; and Akbaba and Alattawi (1995) used a fitting model and the resulting errors over the entire range of characteristic are found to be less than $2 \%$. 
There are other approaches that can be used for estimating the behaviour of photovoltaic cells, such as:

i. Fuzzy logic (Gadeo-Martos et al., 2019);

ii. Polynomial regression (Gianoli-Rossi and Krebs, 1988; Menicucci and Fernandez, 1998; Huld et al., 2011; Wang et al., 2016; Yadava and Chandela, 2017); and

iii. Artificial neural networks (ANN) (Mellit and Pavan, 2010; Almonacid et al., 2013; Mellit et al., 2013; Fathabadi, 2013; Piliougine et al., 2015; Yadava and Chandela, 2017; Al-Waelia et al., 2019; Laarabi et al., 2019).

The main advantage of the artificial intelligence (AI) techniques is the precise results, however, the trade-off culminates in extensive computation. In addition, they, which are based on power rating, can be used without knowing exactly the system under study since it works based on data of the solar module and not based on equations.

Using polynomial regression models, once the system has been characterized and the polynomial coefficients calculated, the power produced by the photovoltaic plant at different ambient conditions can be easily estimated (Huld et al., 2011).

The two biggest disadvantages of polynomial regression and ANNs-based models are: 1) based on the availability of large ambient and electrical data which are necessary for the purpose of characterize the system under study and train the networks; 2) they cannot predict well the current and the voltage - but only during use - when the efficiency of the PV devices changes over time, such in the case of degradation, dust, etc.; in these cases, training with new data should be carried out periodically (Pavan et al., 2014). Nonetheless, the most frequent approaches are the one that model solar cells as electrical circuits: Ortiz-Conde et al. (2006), Chaibi et al. (2018); Jaimes and Sousa (2017); Mares et al. (2015); Cibira and Koscová (2014); Lineykin et al. (2014); Peng et al. (2014); Mahmoud and Xiao (2013); Orioli and Gangi (2013), Ishaque et al. (2011b); Di Piazza et al. (2013); Kumar and Panchal (2013); Das et al.( 2015).

The model parameters are intimately related to the physical mechanisms acting internally in the PV device (Ortiz-Conde et al., 2006), i.e. linking to minority-carrier diffusion mathematical statement. The accessibility of the standard electrical software where the PV model can be perfectly unified into a larger PV system is the main convenience of using the electrical circuit model (comprising of power converter, grid connectivity, expansion and reduction of the PV plant, etc.) (Chin et al., 2015). These models may be applied for the determination of the $\mathrm{P}$ and $\mathrm{I}-\mathrm{V}$ curve at any ambient condition. Then, they allow an entire insight of the PV device, however, they also introduce the need for a series of parameters which are not available from manufacturers' datasheets (i.e. the series and shunt resistances, the diode ideality factor, the diode reverse saturation current, the band-gap energy of the semiconductor, etc.). Furthermore, these parameters strongly vary with the ambient conditions (i.e. irradiation, temperature, etc.) (Sites et al., 1990; Brus, 2012). Some researchers have developed mathematic techniques for these extractions of parameters, either from the datasheet of manufacturers or from experimental data (Villalva et al., 2009; De Soto et al., 2006; Sera et al., 2007; Mahmoud and Xiao, 2013). Therefore, the determination of the $\mathrm{P}$ and $\mathrm{I}-\mathrm{V}$ curve is not immediate, as there is the need of one additional step (i.e. the one for the determination of these parameters) which require iterative calculations and a significant computational effort. In fact, the datasheet normally gives only a restricted data set for PV modules, such as the open-circuit voltage, the short-circuit current, the maximum power current and voltage. Moreover, these data are normally available only at STC, but they are rarely the real condition of operation. In addition, these methods are sensitive to the initial values and, sometimes, depending on initial guess values, they fail to converge (Lun et al., 2013).

Cotfas et al. (2013) made a comprehensive review on 34 different procedures developed to extract the five parameters in single diode model. Chin et al. (2015) deliberated works on the modelling and parameters estimation of PV cells for simulation. It provided the concepts, features, and highlighted the advantages and drawbacks of three main PV cell models, namely 1D1R, 1D2R and 2D2R model.

As well known, only a portion of solar irradiation incident to the PV cell is converted into electricity. The rest of the energy is converted into heat, which overheats the PV module that consequently causes reduction in its performance. Rahman et al. (2015) performed an experiment to observe the effects of varying various operating parameters such as irradiation intensity, cooling fluid mass flow rate, humidity, and dust.

Zaharatos et al. (2015) made available a detailed discussion about the characteristics of PV cell model parameter estimation problem. They looked to an established method called data cloning to check for evidence that the model and key performance parameters are inestimable or non-identifiable. Jordehi (2016) divided the existing research works (more than 50) on PV cell model parameter estimation problem into three groups and the research works of those categories were reviewed. Ayop and Tan (2017) provided a template for the researcher to design the PV emulator according to the requirements established from the tested system. The PV emulator consisted of three parts which are the PV model, the control strategy and the power converter. Fouad et al. (2017) made an integrated review of the diverse factors that affect the performance of PV technology and how those factors affect the performance of the PV system. They listed environmental, PV system, installation and miscellaneous factors. They pointed that solar irradiance, temperature, dust accumulation, shading and soiling factors are some of the environmental concerns that have major effects. 


\section{Contributions}

As the literature on the subject "equivalent models for photovoltaic cell" is very large and dispersed, the availability of a single cohesive and comprehensive document on the subject is crucial to gather information and understand the big picture. Therefore, this work is suitable for new scholars, practitioners, as well as researchers and experienced professionals to not only keep up with, but also to update their knowledge in the latest developments in the field of photovoltaic modeling and simulation, especially in understanding the related physical mechanisms acting internally in the PV device, i.e. linking to minority-carrier diffusion mathematical statement.

This work contributes to the scientific society by discussing 10 different types of equivalent models used to simulate a photovoltaic cell, punctuating their differences, fields of application and, in detail, their respective characteristics regarding the adequacy in representing the physical phenomena inherent to this sustainable technology. In addition to the mathematical analysis, a detailed physical analysis of each of the parameters present in the models allows a better understanding of the simulation capacity of solar cells.

The existing works within the scope of equivalent models are evaluated from 4 perspectives: error analysis, technology (material) of the solar cell, operating conditions, requirements and complexity. The main equations used to describe the physical behaviour of the solar cell were discussed. It was observed that some works still use translation equations that are said to be "inappropriate", "imprecise". It is also evident that inaccurate models are still used due to the lack of knowledge about better ones, or simply assuming that the "more recently developed is better".

\section{Work Structure}

In order to determine all the main existing equivalent models of the implicit type, a research was carried out selecting the most recurring ones, having all their characteristics gathered in PHOTOVOLTAIC MODEL: LOOKING AT PV PHYSICS ASPECTS section.

In CLASSIFICATION OF THE EQUIVALENT MODELS section, in order to enable the evaluation and comparison of the methods developed from the existing equivalent models, three optics were defined: number of parameters, translation equations and solar cell material/technology.

The result of the comparison of the methods developed from the existing equivalent models are in fourth section, where it was possible to establish some rankings, considering the comparison optics previously established. Still in this section, qualitative and quantitative analyzes of error were developed from the information contained in the existing works.

The conclusions and some directions for future research are provided in the following section.

\section{PHOTOVOLTAIC MODEL: LOOKING AT PV PHYSICS ASPECTS}

During the past decades, there were many efforts to model the solar cell. The conception of a circuit model usually starts from the basic principles of physics of semiconductors, taking into account the influence of ambient conditions that is analyzed from the thermodynamics. There is no general agreement, currently, on which singular equation which can be used for modelling the I-V characteristic of the PV cell. However, most models of the solar cells have as starting point the Shockley theory of illuminated p-n junction (Mares et al., 2015). Thus, the equivalent circuit of the solar cell is described at different levels of approximation (Mares et al., 2015). These distinct models, i.e., models with different levels of emulation capability are described next, together with some comments on their particularities. The PV module's I$\mathrm{V}$ characteristic results from the combination of the I$\mathrm{V}$ characteristics of the solar cells that constitute it.

\section{Ideal PV cell model}

The PV cell has fundamentally two layers of individually doped semiconductor material, with its $\mathrm{p}$ $\mathrm{n}$ junction exposed to incident irradiation (Jordehi, 2016; Villalva et al., 2009). With the purpose of diminishing the blockage of incident light, the electrode on the top side is constructed with thin and discontinuous structure with finger-like metal elements ingrained into the silicon (Ciulla et al., 2014). It is designed to diminish the contact resistances and to maximize the absorbing area (Jordehi, 2016).

In the presence of irradiation, the $p-n$ junction absorbs the photons (electromagnetic waves) with energy greater than the band gap of the semiconductor from incident light and create carriers, namely electron-hole pairs (Lorenzo, 2009). All the rest of the photons becomes heat. These carriers are swept away under the influence of the internal electric fields of the $\mathrm{p}-\mathrm{n}$ junction and create a current which is proportional to the incident radiation. This phenomenon is referred to as "photovoltaic effect". The resulting electrical current is named photocurrent and denoted by $I_{p v}$. This current, described by Boltzmann Transport equation, can only be achieved in certain configurations, such as a p-n junction. In contrary, the electron and hole gradients that are similar tend to cancel each other out. The net diffusion currents usually arise only when the electron and hole carrier gradients are very different. In this case of PV cell, currents are dominated by minority carrier diffusion (See Nelson (2003)). 
If the solar irradiation does not exist, the cell acts as a simple $p-n$ junction diode. Its attributes are governed by the well-known Shockley diode equation, which expresses diode current $I_{D}$ as (Chin et al., 2015) Eq. (1):

$$
I_{D}=I_{S}\left[\exp \left(\frac{q V}{a k T}\right)-1\right]
$$

where, $I_{S}$ represents the saturation current and a is the ideality (or quality) factor of the diode. Constant $\mathrm{k}$ is the Boltzmann's constant $\left(1.380653 \times 10^{-23} \mathrm{~J} / \mathrm{K}\right)$, $\mathrm{q}$ is the absolute value of electron's charge (1.60217646 $\mathrm{x}$ $10^{-19} \mathrm{C}$ ), while $\mathrm{T}$ is the temperature of the junction $(\mathrm{K})$. This temperature is generally assumed to be close enough to the temperature of the cell itself. However, it can be accurately determined by transfer heat as done by Akhsassi et al. (2018). The ratio kT/q is known as the thermal voltage $\left(V_{t}\right)$.

The addition of $I_{p v}$ into Shockley equation forms an elementary description of an illuminated PV cell (Chin et al., 2015). The resultant circuit is referred to as ideal PV cell model and is illustrated in Fig. 1. So, I is the superposition of $I_{p v}$ and $I_{D}$, thus, $I_{D}$ determines its shape while $I_{p v}$ defines the translation on the ordinate axis of the curve.

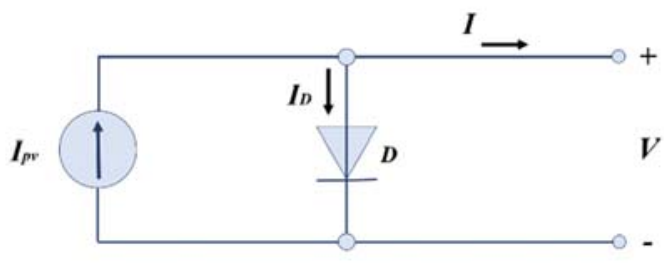

Figure 1. Ideal model of PV cell

It is evident that the mentioned ideal PV cell model has three parameters: $I_{p v}, a$ and $I_{s}$. Its I-V curve characteristic is given by Eq. (2):

$$
I=I_{P V}-I_{S}\left[\exp \left(\frac{q V}{a k T}\right)-1\right]
$$

According to Khan et al. (2013), the $I_{s}$ value is also indicative of the recombination in the bulk of semiconductor materials, while $a$ indicates the recombination at the surfaces of the solar cells and also in the bulk space charge regions. Accordingly, the value of ideality factor notably depends on the PV technology (Cuce et al., 2017).

Bätzner et al. (2001) support that a value depends on the current transport mechanism. A unit value indicates ideal charge transport through the p-n junction, while a value of two corresponds to the superposition of recombination mechanisms and diffusion. When multi-recombination or multitunnelling steps occur, values higher than two can be obtained.

\section{D1R model}

The ideal PV cell model is not commonly used for simulation of PV cells, but it is only used to explain fundamental concepts of PV cells since it cannot emulate the behaviour of physical PV cells (Lim et al., 2015). Therefore, to improve this emulation (Xiao et al., 2004; Chenni et al., 2007), the 1D1R model, which is also known as single diode $\mathrm{R}_{\mathrm{s}}$ model, presents a new element, the series resistance $R_{s}$ as shown in Fig. 2 .

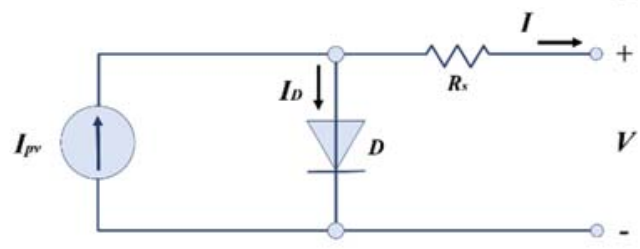

Figure 2. 1D1R model

The presence of the series resistance $R_{S}$ represents the sum of several structural resistances of the device (Soon et al., 2014; Boutana et al., 2017), including the parasitic series resistance (Mazhari, 2006) and dissipative effects (Cuce et al., 2017), the contact resistance of the metal base with the $p$ semiconductor layer, the resistances of the $p$ and $n$ bodies, the contact resistance of the $\mathrm{n}$ layer with the top metal grid (Chin et al., 2015; Cibira and Koscová, 2014), and the resistance of the grid (Khan et al., 2013; Lasnier and Ang, 1990), and finally, the resistance of the materials which compose the module and causes a reduction on the power converted by this device (Ruschel et al., 2016).

This model has four parameters: $I_{p v}, a, I_{s}$ and $\mathrm{R}_{\mathrm{s}}$, and its I-V curve characteristic is given by Eq. (3):

$$
I=I_{p v}-I_{S}\left[\exp \left(\frac{q\left(V+R_{S} I\right)}{a k T}\right)-1\right]
$$

\section{D2R model}

Although 1D1R model imitates the behaviour of physical PV cells better than ideal PV cell model, it can also lack accuracy, especially in the situations where the PV cell presents many defects and/or important temperature variation (Mares et al., 2015). Therefore, to take into account this phenomenon and improve the similarity between model and real PV cell, the 1D2R model, also known as single diode $R_{s h}$ model, presents a new element (Fig. 3): the shunt resistance, $R_{s h}$. Despite the improved performance, the accuracy deteriorates at low irradiances, especially in the proximities of the open-circuit voltage $\mathrm{V}_{\mathrm{oc}}$ (Salam et al., 2010). 


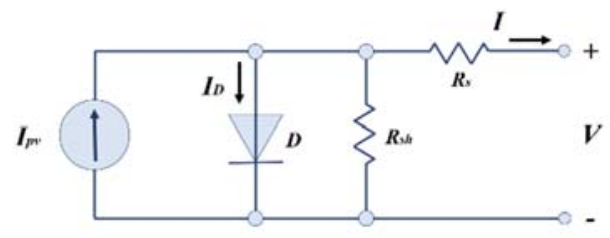

Figure 2. 1D2R model

According to the existing literature, the presence of this shunt resistance represents the construction defects which cause leakage currents within the PV cell (Jordehi, 2016; Boutana et al., 2017), i.e., any parallel high-conductivity paths (shunts) for free carriers produced by the solar irradiation across the PV cell p-n junction or on the PV cell edges (Khan et al., 2013; Mares et al., 2015; Van Dyk and Meyer, 2004). A high shunt resistance means that the clear majority of these carriers generate power, whereas a low resistance indicates large losses (Ruschel et al., 2016). The magnitude of the shunt resistance varies with different fabrication methods since it is intimately related to the construction defects.

This model has five parameters: $I_{p v}, a, I_{s}, R_{s}$, and $R_{s h}$, and its $\mathrm{I}-\mathrm{V}$ curve characteristic is given by Eq. (4):

$$
I=I_{P V}-I_{S}\left[\exp \left(\frac{q\left(V+R_{S} I\right)}{a k T}\right)-1\right]-\frac{V+R_{S} I}{R_{S h}}
$$

Comparing Eqs. (2) and (4), the series resistance affects the output voltage while the shunt resistance reduces the available electrical current.

According to Bai et al. (2014), the shunt resistance is the key parameter to analyse more complex situations of PV cells, PV modules or arrays, such as mismatch and hot-spot phenomena. The fiveparameter model has been confirmed to be more accurate than the four-parameter model (Chegaar et al., 2008; Lo Brano et al. 2012). It is arguably the most popular used PV cell model thanks to its relatively appropriate trade-off between accuracy and simplicity (Jordehi, 2016).

\section{D2R model}

Despite the improved performance of the 1D2R model, its accuracy deteriorates at low irradiances since the single diode models assumed that the recombination loss in the depletion region is absent. In a real solar cell, the recombination represents a substantial loss, which cannot be adequately modelled using a single diode. Consideration of this loss leads to a more precise model, especially in the proximities of $V_{o c}$. Therefore, according to Chan et al. (1987) and Gupta et al. (2012), to overcome this limitation and to take into account the recombination phenomenon, the 2D2R model, which is also known as two-diode model, presents a new element, the second diode $D_{2}$ as shown in Fig. 4.

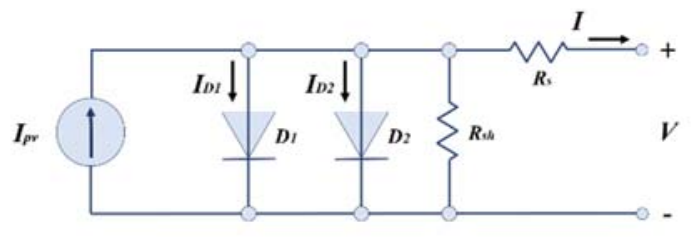

Figure 3. 2D2R model

According to the existing literature, the presence of this second diode represents a global effect due to the presence of a plurality of adjacent and uniformly distributed elementary diodes along the surface that separates the two layers of the semiconductor (Wolf and Rauschenbauch, 1963), i.e., the effect of recombination current loss in the depletion region (Chih-Tang et al., 1957; Gow and Manning, 1999).

This model has seven parameters: $I_{p v}, a_{1}, a_{2}$, $I_{s 1}, I_{s 2}, R_{s}$, and $R_{s h}$, and its $\mathrm{I}-\mathrm{V}$ curve characteristic is given by Eq. (5):

$$
\begin{aligned}
I= & I_{P V}-I_{s 1}\left[\exp \left(\frac{q\left(V+R_{S} I\right)}{a_{1} k T}\right)-1\right]- \\
& I_{S 2}\left[\exp \left(\frac{q\left(V+R_{S} I\right)}{a_{2} k T}\right)-1\right]-\frac{V+R_{S} I}{R_{S h}}
\end{aligned}
$$

In the scientific literature, there are few entirely elucidated models that allow implementing of the algorithm to determine the seven parameters. The transcendental equation and the existence of two exponential terms make the determination of the seven parameters an arduous task. Actually, the procedures demand to be correctly lead during the primary estimation of the parameters to avoid contradictory outcomes; some researchers admit: the primary conditions heavily affect the resolution (Ciulla et al., 2014).

Bail et al. (2003); Khan et al. (2011) and Khan (2012) affirmed that 1D1R and 1D2R model adequately emulate the operating of the solar cells in virtue of insignificant recombination in the space charge region since they are under normal illumination conditions.

Investigating its physical characteristics such as the lifetime of minority carrier, electron diffusion coefficient, intrinsic carrier density and other semiconductor parameters (Hyvarinen and Karila, 2003; Nishioka et al., 2003; Nishioka et al., 2007; Kurobe and Matsunami, 2005) are a substitute approach to characterize the 2D2R model. These models are useful to comprehend the behaviour of the cell, however, knowledge about these parameters is not always accessible in commercial PV letter.

\section{D2R1C model}

This model is similar to the single diode model but with the addition of a capacitance. As shown in Fig. 5. 


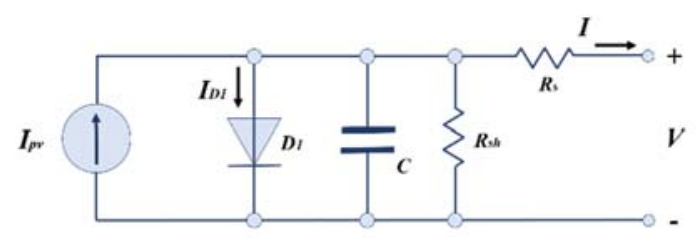

Figure 4. 1D2R1C model

Suskis and Galkin (2013) verified that the voltage on the terminals of the PV panel remains at almost the same value after the instantaneous load connection for 188 microseconds $(\Delta t)$. According to them, this can be explained by $p-n$ junction capacitance that is maintaining the bias at almost the same level, and that after discharge of this characteristics capacitance, the bias drops to the load steady-state value. Thus, a model with included p-n junction capacitance can provide more precise and closer to the reality simulations of transient processes.

\section{D4R model}

All previous models do not provide a wellestablished manner to compare PV cells with each other. An option that enables this comparison is the separation of the diffusion current and recombination current. Kurobe and Matsunami (2005) proposed in his model a "DCA-RCA parallel structure", (Fig. 6), where DCA is a "diffusion-current dominant area", which has an ideal diode of ideality factor equals to unit value, and RCA is a "recombination-current dominant area", which has an ideal diode of ideality factor of two. The analysis introduced by Kurobe and Matsunami (2005) can precisely separate the two current components by using the parameters described in their work, one of these parameters can be associated as a power factor and other as a loss factor, so it is possible that solar cells can be compared with each other, and the way to improve solar cell performance may be easily found.

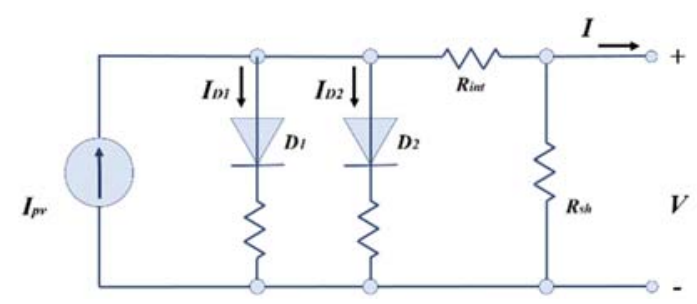

Figure 5. 2D4R model

\section{D2R model}

Mazhari (2006) develops a new simplified model, which is depicted in Fig. 7, based on the assumption that: a) electron-hole pairs generation rate is steady for a given radiation intensity; and b) the energy flux relies upon competition between electron- hole recombination and its collection by the finger-like metal elements.

It is known that the electric field contributes to the current in the solar cells (Lorenzo, 2009) and the electric field is influenced by the voltage, thus, it is expected that current would, in general, depends on the voltage across the solar cell indirectly since the charge extraction efficiency depends on internal electric field.

The difference of this model to previous ones is that the internal series and shunt resistances (it is used the index in lowscript 'int') come into effect only under the presence of light. Furthermore, this model considers the shunt resistance as constant and series resistance as a variable depending on the magnitude of current across it, although both internal resistances can, in general, be functions of externally applied voltage, and non-linear in nature (Mazhari, 2006).

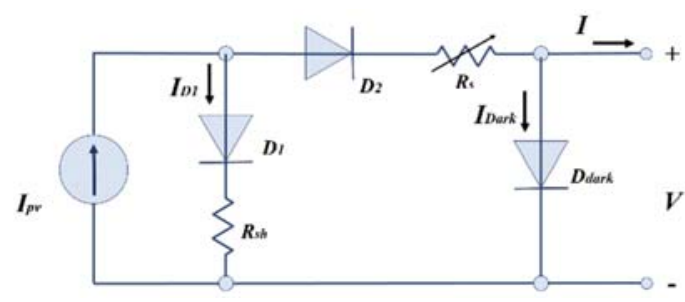

Figure 6. 3D2R model

\section{D5R model}

It was perceived by Nishioka et al. (2007) that when the modelling was with small size solar cells it was difficult to perform precise fitting, because the leakage current through peripheries considerably affects the I-V characteristics of solar cells. With the objective of solve this limitation, the model shown in Fig. 8 was proposed.

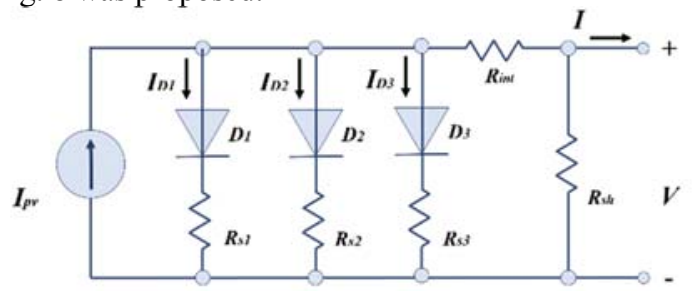

Figure 7. 3D5R model.

The model in Fig. 8 overcomes the limitation of the cells size. Besides, it enables to model small size cells, which is very important, mainly, when it comes to developing cells.

\section{XD2R model}

Soon et al. (2014) demonstrates that different PV models is required to model different $\mathrm{PV}$ cell technologies to achieve low modelling error. The physics meaning of each diode is not explained, but 
the quantity varies according to the necessity of better data's fitting. The model is shown in Fig. 9.

\section{D1R1Rv model}

There are other conduction mechanisms which are described by a nonlinear dependence and most of the classical analysis does not take into account (Pallarès et al., 2006). In literature, it has been reported in CIGS solar cells, GaAs concentrator solar cells and organic solar cells (Mazhari, 2006; Tan and Anderson, 2003; Araki and Yamaguchi, 2003). According to Pallarès et al. (2006), among all the possible conduction mechanisms with a nonlinear currentvoltage dependence, the space-charge limited current (SCLC) mechanism (Rose, 1955) has been reported not only in organic solar cells (Schaeur, 2005; Jain et al., 2005; El-Nahass et al., 2005) but also in amorphous germanium solar cells, porous nanocrystalline $\mathrm{TiO}_{2}$ layers, a-SiC:H/c-Si diodes, a$\mathrm{SiGe} / \mathrm{c}-\mathrm{Si}$ diodes, organic semiconductors, and high-k insulators (Zhu et al., 2004; Eppler et al., 2002; Marsal et al., 2003; Rosales Quintero et al., 2004; Boer et al., 2004; Goldenblum et al., 2005). Thus, Pallarès et al. (2006) proposed an 2D2R adapted equivalent circuit model whose has the addition of an SCLC mechanism to emulate the nonlinear current-voltage dependence. This circuit is illustrated in Fig. 10.

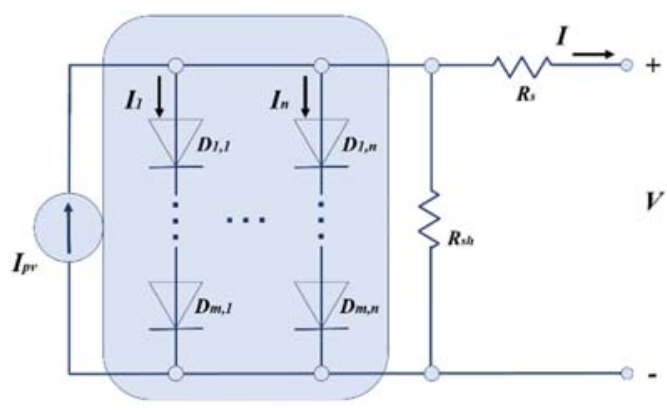

Figure 8. xD2R model

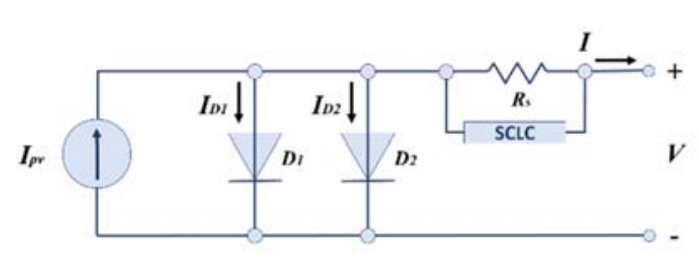

Figure 9. 2D1R1Rv model

\section{Applicability}

Resuming the main characteristics of each model available (Tab. 1) is pertinent to allow the interested people to choose the best option at specific applications since the models have different levels of emulation capability, and some particularities, as above mentioned.

\section{CLASSIFICATION OF THE EQUIVALENT MODELS}

There are many ways for classifying equivalent circuit models. The most common criteria are listed in sequence.

Table 1. The main goal of 10 different equivalent circuit models for PV cell.

\begin{tabular}{|c|c|}
\hline Model & Main goal \\
\hline $1 \mathrm{D}$ & $\begin{array}{l}\text { Explain fundamental concepts of PV } \\
\text { cells. It cannot emulate the behavior } \\
\text { of physical PV cells. }\end{array}$ \\
\hline 1D1R & $\begin{array}{l}\text { Take into account dissipative effects, } \\
\text { and the sum of several contact } \\
\text { resistance and the resistance of the } \\
\text { materials which compose the module } \\
\text { and causes a reduction on the power } \\
\text { converted by this device. }\end{array}$ \\
\hline $1 \mathrm{D} 2 \mathrm{R}$ & $\begin{array}{l}\text { Be more robust in relation to } \\
\text { temperature influence. Emulates the } \\
\text { behavior of construction defects } \\
\text { which cause leakage currents within } \\
\text { the PV cell. }\end{array}$ \\
\hline $2 \mathrm{D} 2 \mathrm{R}$ & $\begin{array}{l}\text { Improve the accuracy deteriorates at } \\
\text { low irradiances. Does not assume that } \\
\text { the recombination loss in the } \\
\text { depletion region is absent. }\end{array}$ \\
\hline 1D2R1C & $\begin{array}{l}\text { Emulate transient processes of the } \\
\text { voltage on PV cell terminals in the } \\
\text { instantaneous } \\
\text { connection/disconnection }\end{array}$ \\
\hline 2D4R & $\begin{array}{l}\text { Proportionate the division of the } \\
\text { current into two components } \\
\text { associated to power factor and other } \\
\text { as a loss factor, so it is possible that } \\
\text { solar cells can be compared with each } \\
\text { other, and the way to improve solar } \\
\text { cell performance may be easily } \\
\text { found. }\end{array}$ \\
\hline $3 \mathrm{D} 2 \mathrm{R}$ & $\begin{array}{l}\text { Consider: 1) the polaron-pair } \\
\text { generation rate as constant for a given } \\
\text { light intensity, rather than the current; } \\
\text { 2) the current depends on competition } \\
\text { between polaron recombination and } \\
\text { its dissociation/collection by the } \\
\text { electrodes }\end{array}$ \\
\hline $3 \mathrm{D} 5 \mathrm{R}$ & $\begin{array}{l}\text { Model small size solar cells since it } \\
\text { present leakage current through } \\
\text { peripheries. }\end{array}$ \\
\hline $\mathrm{xD} 2 \mathrm{R}$ & $\begin{array}{l}\text { Model different PV cell technologies } \\
\text { to achieve low modelling error }\end{array}$ \\
\hline 2D1R1Rv & $\begin{array}{l}\text { Emulate other conduction } \\
\text { mechanisms which are described by a } \\
\text { nonlinear dependence and most of the } \\
\text { classical analysis does not } \\
\text { considered. It was used an SCLC } \\
\text { mechanism. }\end{array}$ \\
\hline
\end{tabular}




\section{Classification according to number of parameters}

The usual models (1D, 1D1R, 1D2R and 2D2R model) can belong to three-variable, four-variable, five-variable or seven-variable. Each increment on the number of parameters represents a physical meaning that approximates the model to reality. The $1 \mathrm{D}$ model is the basic and the 2D2R model is the most complex between the usual ones. Recently others models (from 1D2R1C to 2D1R1Rv model) - that can belong to sixvariable, nine-variable or twelve-variable - were developed to better simulate the behaviour of the PV cell in specifics aspects that were not covered by the usual ones. The xD2R model, in specific, is the only model that does not have a defined number of parameters since it adapts itself to the PV cell so that an optimal representation is achieved - this adaptive capacity is not explained in a physical way.

The more variables the more accuracy the model will have. This expected since more technical features are being taken into account. However, the accuracy increment implies in complexity and time-consuming. The trade-off between accuracy and simplicity explains why, in practice, the 1D2R model (Fig. 3) is mostly used (Barukcic et al., 2014).

In the usual regime of a solar cell (medium irradiance level) the diffusion current dominates and, therefore, the diode $D_{2}$ from Fig. 4, which represents the generation-recombination current, can be omitted - see e.g. (Sah, 1991) - which results in the 1D2R model. However, in low irradiance level, at $V_{o c}$, the $1 \mathrm{D} 2 \mathrm{R}$ model normally shows divergences from the experimental data, suggesting that it is inadequate in these operation conditions, thus, this behaviour compromises its emulating performance have significant impact during partial shading (Ishaque et al., 2011a) which is usual during solar cell operation.

It is important to recall that the division made in this work is based in the number of the initial parameters for each equivalent circuit model, i.e., before any assumptions/hypothesis that simplifies the model be adopted, such as, sets the value of the ideality factor which would reduce the number of unknowing parameters.

\section{Classification according to translation equations}

The effect of different operational conditions on the temperature of a PV module was found to be dependent on the actual electrical efficiency, and to have a considerable value, so that it cannot be negligible (Kurnik et al., 2011). At PV technologies, the PV temperature and incident solar radiation are the main factors that affect their behaviours and therefore should be considered during their respective modelling. However, others factors, such as ambient temperature, wind speed and direction, dusty, humidity and mounting structure will influence in a secondary way, modifying how the main ones will behave (Tonui and Tripanagnostopoulos et al., 2007; Faiman, 2008). For free-standing modules, in a normal summer day in Germany with an irradiance of 800 $\mathrm{W} / \mathrm{m}^{2}$ and an ambient temperature of $20{ }^{\circ} \mathrm{C}$, the common module temperature is around $42{ }^{\circ} \mathrm{C}$ (Schwingsackl et al., 2013), while during summer days in Central Europe, it can easily reach $60^{\circ} \mathrm{C}$. In extreme conditions, the PV module temperature can exceed 80 ${ }^{\circ} \mathrm{C}$ in Ouarzazate-Morocco (Oukili et al., 2013).

The electrical parameters of PV modules are usually measured by the manufacturers at Standard Test Conditions (STC) - an irradiance level of 1000 $\mathrm{W} / \mathrm{m}^{2}$, a cell temperature of $25^{\circ} \mathrm{C}$ and an air mass $\mathrm{AM}$ $=1.5$ spectrum - neither the electrical parameters of PV modules at the normal operating cell temperature (NOCT). This condition is defined by IEC 61215 (2005) standard (IEC61215, 2005), which is measured on an open rack-mounted module with an inclination of $45^{\circ}$, an irradiance level of $800 \mathrm{~W} / \mathrm{m}^{2}$, an ambient temperature of $20{ }^{\circ} \mathrm{C}$ and a wind speed of $1 \mathrm{~m} / \mathrm{s}$. However, in view of the interdependent behaviour described above, such specifications are not enough to describe all situations that one PV module can operate. This leads to the necessity of translation equations that can relate the STC or NOCT to the real ones that are experimented by the PV cell. It is important to note that in this work, the analyses will depart from the final behaviour of temperature and irradiation after being influenced by its secondary factors. The relation between the main and secondary factors can better understood at the works of Radziemska (2003), Rawat et al. (2017) and Akhsassi et al. (2018).

The semiconductor material most important physical properties that change with temperature are: the band gap, and the minority-carrier lifetime. When the temperature rises: the band gap decreases its value since the electrons moves easier and, consequently, the space between the valance and conduction bands is reduced; whereas the minority-carrier lifetime increases since there is more energy. The temperature increase also causes a significant build-in voltage drop, the potential barrier of the $p-n$ junction of the solar cell and the separation ability of the junction as well (Radziemska, 2002).

\section{- Common equations}

The most common translation equations are based on the manufactured datasheet. Data obtained empirically, such as, temperature coefficient of shortcircuit current $\left(\mu_{I_{s c}}\right)$ and of open-circuit voltage $\left(\mu_{V_{o c}}\right)$ are available which proportionate the use of:

$$
\begin{aligned}
& I_{S C}=I_{S c, r e f}+\mu_{I_{S C}}\left(T-T_{r e f}\right) \\
& V_{O C}=V_{O C, r e f}+\mu_{V_{o c}}\left(T-T_{r e f}\right)
\end{aligned}
$$

When the irradiation is taken into account, the Equations (6) and (7) are, respectively, modified to become: 


$$
\begin{aligned}
& \quad I_{s c}=\frac{G}{G_{r e f}}\left[I_{s c, r e f}+\mu_{I S C}\left(T-T_{r e f}\right)\right] \\
& V_{O C}=V_{O C, r e f}+a V_{t} \ln \left(\frac{G}{G_{r e f}}\right) \\
& +\mu_{V_{O c}}\left(T-T_{r e f}\right)
\end{aligned}
$$

However, it is usual to admitted that the other parameters are influenced by the operation conditions, such as the light-generated current $\left(I_{p v}\right)$, cell saturation current $\left(I_{S}\right)$, the band gap $\left(E_{g}\right)$, the ideality factor $(a)$, the series $\left(R_{s}\right)$ and shunt $\left(R_{s h}\right)$ resistance. These relations are usually expressed by the Eqs. (10) - (15).

$$
\begin{gathered}
I_{p v}=\frac{G}{G_{r e f}}\left[I_{P V, r e f}+\mu_{I_{p v}}\left(T-T_{r e f}\right)\right] \\
I_{s}=I_{s, r e f}\left(\frac{T}{T_{r e f}}\right)^{3} \exp \left[\frac{q}{a k}\left(\frac{E_{g, r e f}}{T_{r e f}}-\frac{E_{g}}{T}\right)\right] \\
\frac{E_{g}}{E_{g, T_{r e f}}}=1-0.0002677\left(T-T_{r e f}\right) \\
\frac{a}{a_{r e f}}=\frac{T}{T_{r e f}} \\
\frac{R_{S}}{R_{s, r e f}}=\frac{G_{r e f}}{G} \\
\frac{R_{s h}}{R_{s h, r e f}}=\frac{G_{r e f}}{G}
\end{gathered}
$$

It is known that the band gap decreases with temperature and it makes possible for more and more electrons to overcome the band gap by means of thermal activation and the increase of the dark saturation current (Radziemska, 2003). Thus, it is sensible to affirm that Equations (11) and (12) are in accordance with the physical aspects of the solar cells.

\section{- Recent developed equations}

According to Orioli and Di Gangi (2013), the above expression of $V_{O C}$ (Eq. 9), is quite imprecise because it was obtained from Eq. (4) on the basis of the simplified hypotheses of the 1D1R model, in which it is $R_{s h}=\infty$. Moreover, when the irradiance tends to zero, Equation (9) yields an unrealistic value of the open circuit voltage $\left(V_{o c} \rightarrow-\infty\right.$.). Thus, these authors proposed the Eq. (16) based on the I-V characteristics of 108 models of PV panels (among heterojunction with intrinsic thin layer, polycrystalline and monocrystalline silicon) issued on the Internet by 23 manufacturers.

$V_{o c}=V_{o c, r e f}+\left\{C_{1} \ln \left(\frac{G}{G_{r e f}}\right)+C_{2} \ln \left(\frac{G}{G_{r e f}}\right)^{2}+\right.$

$\left.C_{3} \ln \left(\frac{G}{G_{r e f}}\right)^{3}\right\}+\mu_{V_{o c}}\left(T-T_{\text {ref }}\right)$

where $C_{1}=5.468511 \times 10^{-2} ; \quad C_{2}=5.973869 \times$ $10^{-3}$, and $C_{3}=7.616178 \times 10^{-4}$.

Depending to the paper, Equation (13) became Eq. (20), Equation (14) became Eq. (17), and Equation (11) became Eq. (18) or Eq. (19), i.e., in both cases the band gap is considered as constant in function of temperature.

$$
\begin{gathered}
R_{S}=R_{s, \text { ref }} \frac{T}{T_{\text {ref }}}\left(1-0.217 \ln \frac{G}{G_{\text {ref }}}\right) \\
I_{S}=I_{s, \text { ref }}\left(\frac{T}{T_{\text {ref }}}\right)^{3} \exp \left[\frac{q E_{g, r e f}}{a k}\left(\frac{1}{T_{\text {ref }}}-\frac{1}{T}\right)\right] \\
I_{S}=I_{s, \text { ref }}\left(\frac{T}{T_{\text {ref }}}\right)^{3} \exp \left[\frac{q E_{g, r e f}}{a k}\left(1-\frac{T_{\text {ref }}}{T}\right)\right] \\
\frac{a}{a_{\text {ref }}}=\frac{G}{G_{\text {ref }}}
\end{gathered}
$$

De Soto et al. (2006) developed an expression where $I_{p v}$ depends not only on radiation and temperature as on Eq. (10), but also on the air mass modifier (M). Therefore, it was proposed a modification to yield Eq. (21). The air mass modifier is assumed to be a function of the local zenith angle. Radiation data are not normally known on the plane of the PV panel, so this work proposed a methodology to estimate the absorbed solar radiation using horizontal data and incidence angle information. As aforementioned, the study of how the ambient conditions influence on the irradiation and temperature that hits the PV cell/module is not the focus of this paper, and therefore, methodologies on that issue will not be detailed.

$$
I_{p v}=\frac{G}{G_{r e f}} \frac{M}{M_{r e f}}\left[I_{p v, r e f}+\mu_{I_{s c}}\left(T-T_{r e f}\right)\right]
$$

Lo Brano et al. (2010) performed several calculations of $I_{S}$ in the open circuit point using data collected from the I-V curves provided by manufacturers and referred to several PV panels at the standard temperature and at the irradiances included between 200 and $1000 \mathrm{~W} / \mathrm{m}^{2}$. His findings show a regular dependence of the saturation current on the solar irradiance. With a good approximation, the reverse saturation current can be expressed by:

$$
I_{S}=\exp \left[\left(\frac{\frac{G}{G_{r e f}}-0.2}{1-0.2}\right) \ln \frac{I_{S}(1, T)}{I_{S}(0.2, T)}+\ln I_{S}(0.2, T)\right]
$$

Lo Brano et al. (2010) also affirmed that expressions like Eq. (9) or similar, do not have the desired accuracy, thus he proposed the Eq. (23) for the cell voltage. The thermal correction factor $\mathrm{K}$ (Eq. 24) is used to slide the I-V characteristic at irradiance $G_{r e f}$ on the $\mathrm{V}$ axis in order to better fit the characteristics issued by the manufacturer at temperatures $\mathrm{T}^{*}$ different than $T_{\text {ref }}$. The value of $\mathrm{T}^{*}$ to be used to determine $\mathrm{K}$ should be chosen by considering the maximum or the minimum expected working temperature of the PV module and, obviously, the data provided by the manufacturer. In his paper, it was used the temperature of $\mathrm{T}^{*}=75^{\circ} \mathrm{C}$. 


$$
\begin{aligned}
V_{\text {fitted }} & =\frac{G}{G_{r e f}}\left[V+K I\left(T-T_{\text {ref }}\right)\right] \\
K & =\frac{V_{m p}-V_{m p}^{*}}{I_{m p}^{*}\left(T^{*}-T_{r e f}\right)}
\end{aligned}
$$

where $V_{m p}^{*}$ and $I_{m p}^{*}$ are the coordinates of maximum power point at $T=T^{*}$.

In order to avoid using graphical information from the datasheet, Orioli and Di Gangi (2013) proposed:

$$
\begin{aligned}
& R_{s 0}=C_{s} \frac{V_{o c}}{I_{s c}} \\
& R_{s h 0}=C_{s h} \frac{V_{o c}}{I_{s c}}
\end{aligned}
$$

that allows the $R_{s 0}$ and $R_{s h 0}$ calculation. Where, for silicon technology: $C_{s}=0.11175$ and $C_{s h}=34.49692$; and for HIT (Heterojunction with Intrinsic Thin layer) technology: $C_{s}=0.11175$ and $C_{s h}=34.49692 .144$ different PV modules were used to define these two following equations, it involved HIT, monocrystalline and polycrystalline silicon technology.

Mares et al. (2015) performed some tests and demonstrated that there is a limited domain in the plane $\left(R_{s 0}, R_{s h 0}\right)$ for which the algorithm is convergent. In the following, he called this $2 \mathrm{D}$ domain of 'running window'. It is obvious that inside the running windows a couple $\left(R_{s 0}, R_{s h 0}\right)$ exists for which the numerical solution best approximates the experimental I-V curve. The Equations that obtain this couple are:

$$
\begin{gathered}
R_{s 0}=0.002102+0.318070 \frac{V_{o c}-V_{m}}{I_{m}} \\
R_{s h 0}=-0.051914+2.505219 \frac{V_{m}}{I_{s c}-I_{m}}
\end{gathered}
$$

18 different PV modules were used to define these two following equations, it involved monocrystalline and polycrystalline silicon technology.

\section{Classification according to PV technology}

PV technology can be classified in three generations: first, second or third-generation technology (Sampaio and González, 2017). Firstgeneration PV technologies are predominantly based on bulk silicon such as monocrystalline (mc-Si), polycrystalline (pc-Si), and ribbon sheets. Secondgeneration PV technologies are based on thin films such as amorphous silicon (a-Si), copper indium diselenide (CIS), copper indium gallium diselenide (CIGS), cadmium-telluride (CdTe) and multi-junction cells. Third-generation technologies are emerging technologies that use perovskite, passivated emitter and rear cells (PERC), and nanocrystalline films.

Market share of polycrystalline $(56 \%)$ and monocrystalline $(36 \%)$ based solar cell was predominant, and it was followed by CdTe (5\%),
CIGS (2\%), and amorphous-Si $(<1 \%)$ in 2014 (Ramanujam et al., 2016).

As aforementioned, $a$ indicates the recombination in the bulk space charge regions and at the surfaces of the solar cells. Therefore, it is reasonable that the value of ideality factor depends on the PV technology. In literature, $a$ usually ranges from 1 to 2 for silicon PV modules (Kippelen and Bredas, 2009). This parameter affects the $\mathrm{J}-\mathrm{V}$ curve, as shown in Fig. 11, where the value of $a$ varies, i.e., it influences the accuracy of the models. In Tab. 2 is presented some guesses for assumptions related to $a$ values for different $\mathrm{PV}$ technologies.

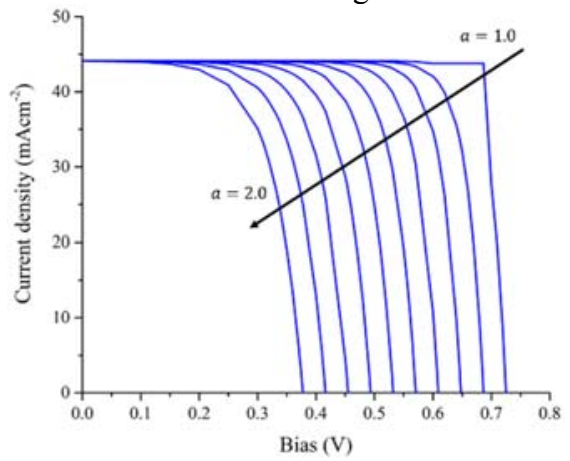

Figure 10. Influence of ideality factor on the J-V curve of a silicon ideal solar cell.

Table 2. The value of ideality factor for different PV technologies (Cuce et al., 2017).

\begin{tabular}{lc}
\hline PV technology & $\boldsymbol{a}$ \\
\hline Si-mono & 1.20 \\
Si-poly & 1.30 \\
a-Si:H & 1.80 \\
a-Si:H tandem & 3.30 \\
a-Si:H triple & 5.00 \\
$\mathrm{CdTe}$ & 1.50 \\
$\mathrm{CIS}$ & 1.50 \\
$\mathrm{GaAs}$ & 1.30 \\
\hline \multicolumn{2}{c}{} \\
EVALUATING $\quad$ THE & MOST \\
EQUIVALENT MODELS &
\end{tabular}

The process of ranking the models analysed by this work was divided in two parts: 1) literature research; and 2) comparative and qualitative analysis using the criteria presented in the last section. In order to know what models should be compared, an intensive research on the literature was carried out aiming to make a list of the available equivalent circuit models, and to establish relations based on the available information. The result of this first step is presented in Fig. 12.

On the literature, mainly in Fig. 12, there are many relations between the existent models. These relations were separated in three groups: 1) Worse than: it is used when during the article the author(s) proved by error data that his (their) model is more 
efficient than the other in question; 2) Indecisive: it is used when the model was compared to others or not, in case of comparison, no quantitative results were given in order to affirmed which is more efficient, in case of no comparison, the used information was extracted from datasheet and/or experimental data; and 3) Base for: it is used when the model was a base for another one and there are not relations that can be classified in the first two groups.

Based on Fig. 12, ten models were selected to be qualitatively compared in terms of PV technology, operation conditions, translation equations, and assumptions and time-consuming level. The corresponding literature are: Chaibi et al. (2018); Boutana et al. (2017a); Jaimes and Sousa (2017); Mares et al. (2015); Cibira and Koscová (2014); Lineykin et al. (2014); Peng et al. (2014); Mahmoud and Xiao (2013); Orioli and Gangi (2013); and Ishaque et al. (2011b). This prior selection method was based on the most recent models, and also on their accuracy.

\section{PV technology}

The models are usually said to be useful in many different PV technologies (See Section 3.4). However, it is worthy to highlight that the performance generally goes down when a model is used in a situation other than that used to validate itself. Thus, it is pertinent to classify the selected models based on the cell material (Tab. 3).

The ranking on "PV technology" criteria was made based on the following aspects of the models: 1) Different PV technologies; 2) Number of PV module/cells. These criteria were chosen since the model would better emulate different PV module technology with less dispersion. When necessary, the tie-breaking criterion was the most recent model. It was supposed that be better than the previous models under the same aspects is a condition to be accepted by the scientific community. The Table 3 indicates the number of PV modules used in each work and, in parentheses, the number of PV modules used to evaluate the model.

\section{PV operation conditions}

As already discussed, the operation conditions of a PV module affect directly its performance. These distinct circumstances are due to locality, seasons or yet to Earth's position to the sun. Thus, it is important a ranking where the criterion is the "PV operation conditions" (Tab. 4) to better emulate in different conditions in a more accurate way with less dispersion.

The ranking on "PV operation conditions" criteria was made based on the following aspects of the models: 1) Different operation conditions; 2) Experimental data from literature and not just datasheet information; 3) Number of PV technology at each different condition. These criteria were chosen since the model would better emulate at different operation conditions, using also experimental data. Besides, the number of different PV technology was selected to be the last criteria since it had already been computed in the previous criteria. When necessary, once more, the tie-breaking criterion was the most recent model.

During the research, some PV modules present large data and it is recommended its use, such as: $\mathrm{KC}$ 200GT, S36, SW255, SQ150-PC, SP-70, SM 55 and ST40.

\section{Translation equations}

The presence of translation equations is important since it reduces the necessity of large data. Besides, using this approach it is possible to relate the operation conditions directly to each parameter. The ranking on "Translation equation" (Tab. 5) criteria was based on the following aspects of the models: 1) Number of parameters having translation equations; 2) Equations recently developed; 3) Number of parameters considered. These criteria were chosen since the model would better emulate the real condition if the maximum of parameters is considered using recent well-established equations. When necessary, once more, the tie-breaking criterion was the most recent model.

\section{Assumptions and time-consuming}

The use of assumptions is common for all models. It is used aiming the simplification of some calculus, reducing the time-consuming. Its presence is greater mainly in models that present transcendental equations. However, its facility results in loss of accuracy, thus, it is important to identify and discuss the main assumptions made by the models.

Chaibi et al. (2018), Cibira and Koscová (2014) and Lineykin et al. (2014) assumed that the band gap is constant in function of temperature variation. This assumption brings not just loss of accuracy, but it gets away of reality. It is recommended the use of Eq. (12) since it gives back to the model the physical meaning and it do not increase the time-consuming because it is a simple equation.

The use of lambert W-function $f(W)=W e^{W}$ is adopted by Cibira and Koscová (2014) 0, Lineykin et al., 2014, Peng et al. (2014). This method reduces the time-consuming since it was developed to solve exponential equations since it can be seen as the inverse function of $f(W)$.

The assumption of $I_{p v \text {,ref }}=I_{s c, r e f}$ used by Chaibi et al. (2018), and Cibira and Koscová (2014) is widely accepted, however, the use of $R_{s h} \gg R_{S}$ used by Peng et al. (2014) and Chaibi et al. (2018) and $R_{S}=$ $I_{s c} / 40$ used by Cibira and Koscová (2014) are not. The acceptation or rejection by the scientific community is related, respectively, to the reduction at timeconsuming and to the loss of accuracy. 
Generally, the ideality factor $a$ is arbitrarily chosen. Many authors discuss ways to estimate the correct value of this constant (Walker, 2001; Carrero et al., 2007). Usually, $1 \leq a \leq 1.5$ and the choice depends on other parameters of the $\mathrm{I}-\mathrm{V}$ model. As is given in Carrero et al. (2007), there are different opinions about the best way to choose $a$. According to Lineykin et al. (2014), the correct value of $a$ corresponds to the modelled curve with minimum deviation from the datasheet/measured I-V curve at STC. Peng et al. (2014) assumed $a$ is unit; Ishaque et al. (2011b) also used $a_{1}=1$ and $a_{2} \geq 1.2$. In this work, it is defended that the $a$ value has also to be related to the PV technology, and not just a parameter to reduce the deviation of the curve from the datasheet/measured data. Once its value is constant and related to the PV technology, the time-consuming is reduced and the model presents physical meaning.

\section{Overview}

Ishaque et al. (2011b), despite proposing a twodiode modeling method for PV cell, achieved a method that requires the computation of only four parameters and computes the series and shunt resistances using a simple and rapid iterative approach. It presented excellent precision at lower irradiance conditions and it was superior when exposed to temperature and irradiance variations using datasheet information from the manufacturers of six PV modules of different technologies.

Boutana et al. (2017a) developed a model based on a simple I-V mathematical expression where only three parameters are required. This model presented the relatively smallest errors among other four models. Besides, for experimental data, this model achieved results very close to the ones extracted by a powerful optimization tool (FODPSO algorithm). A correlation coefficient value greater than 0.996 for the four PV module technologies was achieved by the model. Furthermore, it can give a good estimation of the maximum power point.

Cibira and Koscová (2014) do not compare to any other work. The error analysis mentioned in the work just comments that differences occur at bending and tail areas (highest difference point at $\mathrm{V}=1.6 \mathrm{~V}$ ); but they do not exceed $2.3 \%$ of measured level. The analysis could be showed at all curve. In the graphics with varying temperature, it was observed an anomalous behavior that needs more attention, it is not in agreed with the general literature.

The model presented in Chaibi et al. (2018) shows good agreement between the proposed method and datasheet, except for irradiance lower than 400 $\mathrm{W} / \mathrm{m}^{2}$. The curve presents a great inclination, and so, a remarkable discrepancy can be observed at vicinities of $V_{o c}$ (it was also observed at (Saloux et al., 2011) and (Das, 2011), different from (Mermoud, 2012) and (Villalva et al., 2009)). Their work made comparisons among their model, well established models and datasheet separately. It is recommended a simultaneous comparison to confirm its accuracy since it is easier to visualize. This model usually underestimates the MPP, thus, it is not the best choice when the aim is the prediction of production energy to study the feasibility of a power plant at maximum production due to the conservative predictions.

Jaimes and Sousa (2017) developed a new model which is very effective in harvesting applications because it forecasts the power constrain introduced by the indoor PVSC apparatus to the payload. In addition, this model forecasts precisely the operation of the indoor PVSC under warm LED spectrum - with illuminance from $177 \mathrm{~lm} / \mathrm{m}^{2}$ to $33.3 \times 10^{3}(0.67-107$ $\mathrm{W} / \mathrm{m}^{2}$ ) - at ambient temperature. However, it is not suitable to be compared to the others models presented here due to its radiation source and application field.

Mares et al. (2015) presented a five-parameter model which was tested on six different commercially available crystalline silicon PV modules. The values of the correlation coefficient $\mathrm{r}^{2}$ are in the range 0.976 0.998 demonstrating a very good agreement between the experimental I-V characteristic and the estimated $\mathrm{I}-\mathrm{V}$ characteristics. However, there are minor differences in two curves. These discrepancies can be attributed to the PV technology, these two modules are mc-Si while the other four are pc-Si, which contributed to the point already discussed: it should be a parameter during the extraction of parameters that differentiate the PV technologies, i.e., the $a$ value. Lineykin et al. (2014) also discussed how the value of the ideality factor affects the curve. Despite this work affirms that its accuracy and the reported by Lo Brano et al. (2010) is comparable, it was not proved by error analysis. However, for running the algorithm of Mares et al. (2015), the graphical presentation of the I-V characteristic in the PV module datasheet is not required, which is a major advantage.

Lineykin et al. (2014) used the minimization of the divergence between the modeled and experimental I-V curves of several off the shelf panels of leading manufacturers to obtain the fifth parameter. The proposed method indicates feasibility and high accuracy through the results of an average deviation of $0.1-0.5 \%$.

For conceiving a general ranking involving all criteria, some aspects were established. Firstly, it was considered the models that present comparisons to any work in the literature, in specific, the ones "worse than" as showed in the Fig. 12. It was the main aspect to rank the models since the superiority was declared by the authors themselves. Secondly, it was considered the different operation conditions followed by different PV technology. This sequence was chosen because all models use silicon technology which represents $80 \%$ of the PV all market (Sudhakar et al., 2016), i.e., the models that use others technologies, despite emulate in a broader variety of technology, the difference is balanced due to the percentage of each 
technology commercialized. Finally, it was computed the ranking of translation equations.

The general ranking is presented in Tab. 6. The error analysis is considered the most important, however, it was observed that is common it not be complete and adequate. It is suggested that this investigation should be like that performed by Boutana et al. (2017a) and Mahmoud and Xiao (2013) that presented graphically the error at all curve $\mathrm{I}-\mathrm{V}$, or at least, as was done by Ishaque et al. (2011b) that computed the error to each different condition. Since it was observed that the most recent is not the best one necessarily, it is indispensable the comparison to other existent models, mainly the ones appointed here as Group 1, and under the same conditions that the first one was developed.

This final ranking is divided in 3 groups. This classification was chosen since it was not feasible to precisely weight each aspect because of lacking quantitative analysis. However, this division is enough and reliable to elect the most appropriate equivalent models for PV cells (group 1): Ishaque et al. (2011b), Orioli and Di Gangi (2013), Mahmoud and Xiao (2013) and Boutana et al. (2017a).

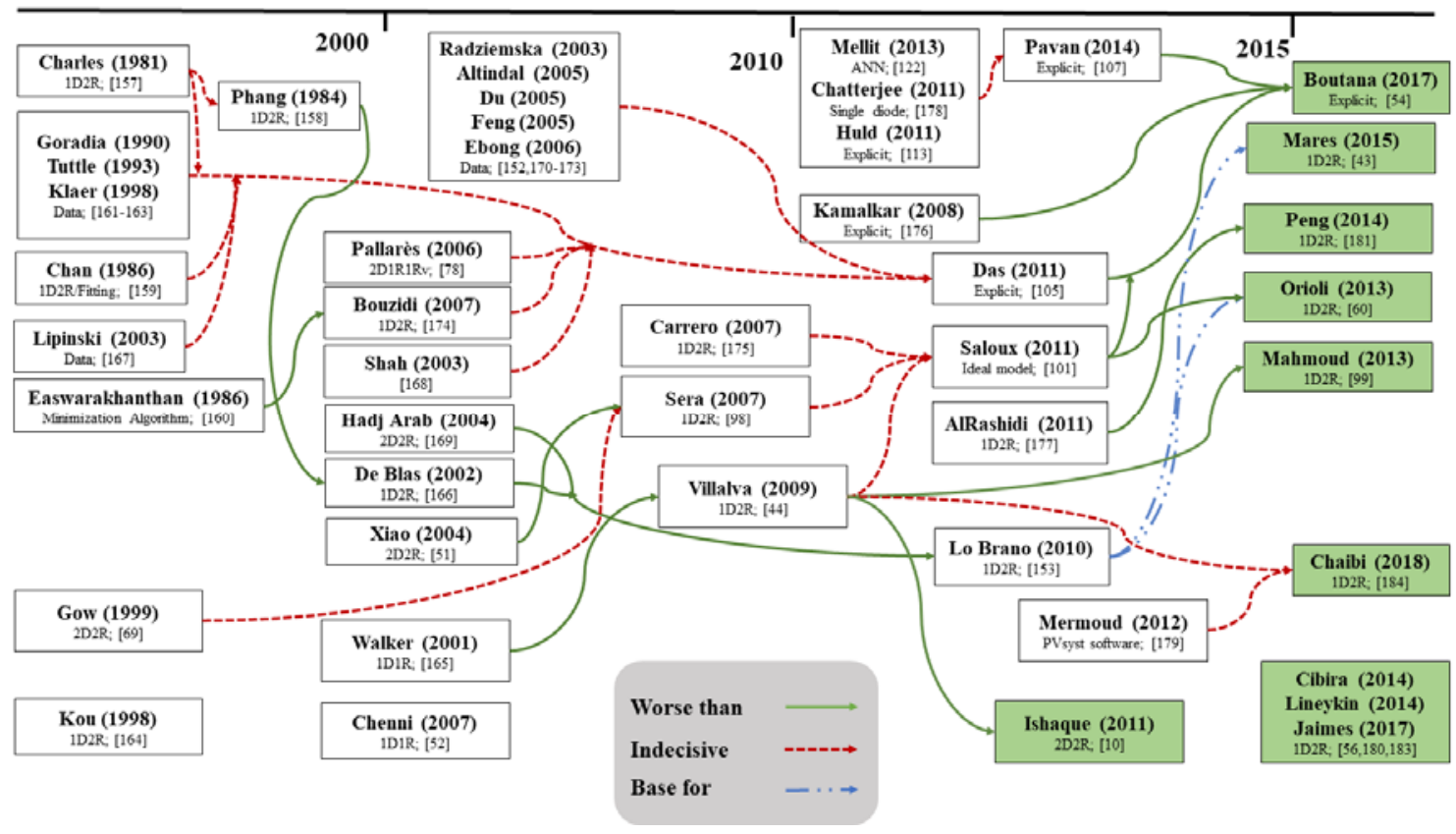

Figure 11. Some equivalent models of solar cell

Table 3. PV technology ranking.

\begin{tabular}{lcccccc}
\hline$\# \mathrm{~N}$ & Paper & mc-Si & pc-Si & CdTe & CIGS & HIT \\
\hline 1 & Boutana et al. (2017a) & $1(1)$ & $1(1)$ & $1(1)$ & $1(1)$ & \\
2 & Orioli and Gangi (2013) & $55(2)$ & $76(1)$ & & & $14(1)$ \\
3 & Mahmoud and Xiao (2013) & $4(4)$ & $7(6)$ & & $2(2)$ \\
4 & Ishaque et al. (2011b) & $3(3)$ & $2(2)$ & & $1(1)$ \\
5 & Mares et al. (2015) & $10(2)$ & $8(4)$ & & \\
6 & Lineykin et al. (2014) & $2(2)$ & $2(2)$ & & \\
7 & Chaibi et al. (2018) & $1(1)$ & $1(1)$ & & \\
8 & Peng et al. (2014) & $2(2)$ & & & \\
9 & Jaimes and Sousa (2017) & $1(1)$ & & & \\
10 & Cibira and Koscová (2014) & \multicolumn{5}{c}{$1(1)$} \\
\hline \multicolumn{7}{c}{ Number of PV modules used in the work (number of PV modules used to evaluate the model) }
\end{tabular}




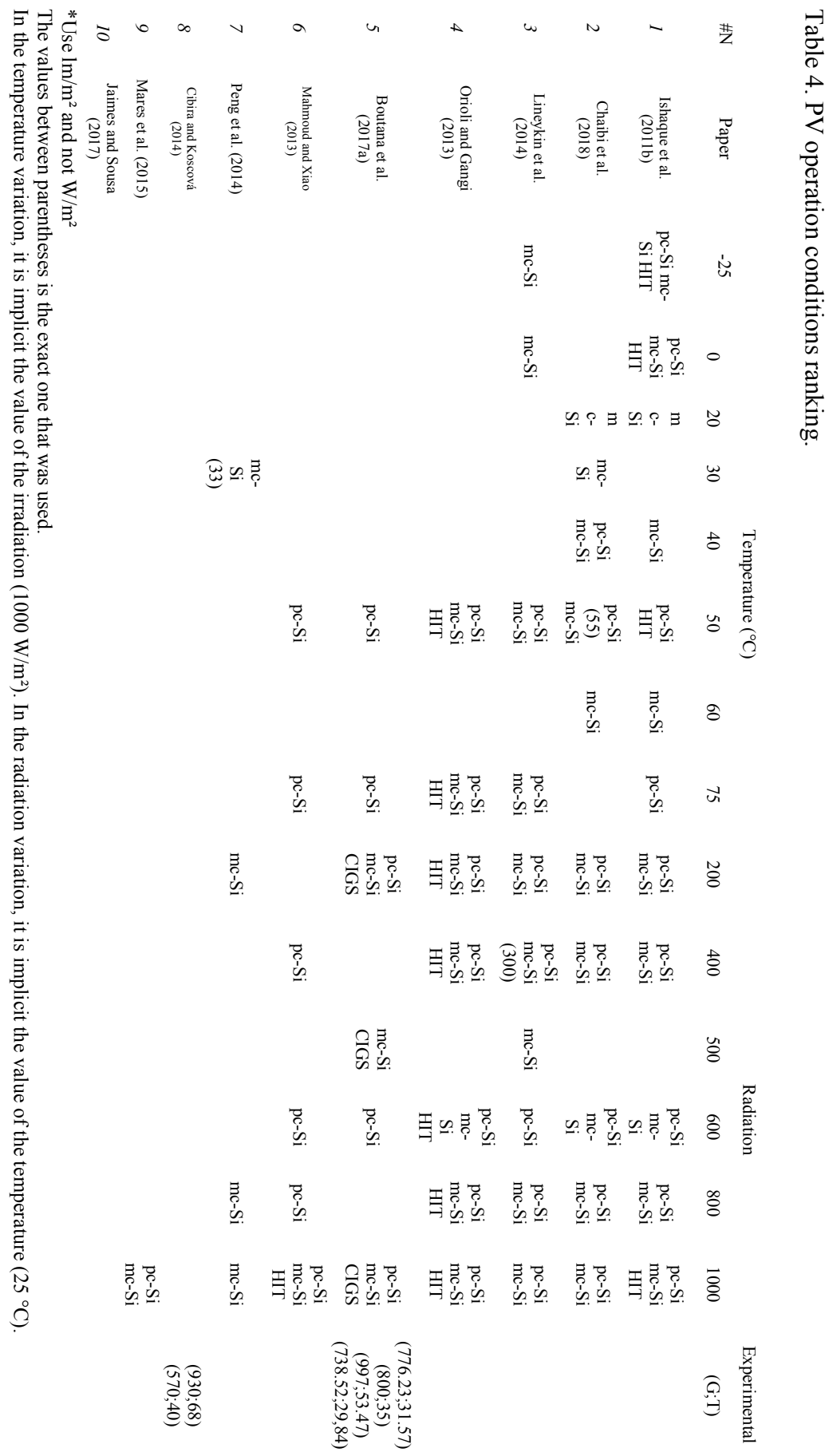


Table 5. Translation Equations' ranking.

\begin{tabular}{|c|c|c|c|c|c|c|c|c|c|c|c|}
\hline \multirow{2}{*}{$\# \mathrm{~N}$} & \multirow{2}{*}{ Paper } & \multicolumn{10}{|c|}{ Translation Equations } \\
\hline & & $I_{m p}$ & $I_{p v}$ & $I_{s c}$ & $V_{m p}$ & $V_{o c}$ & $I_{S}$ & $E_{g}$ & $a$ & $R_{S}$ & $R_{s h}$ \\
\hline 1 & Orioli and Gangi (2013) & - & $(10)$ & - & (23) & (10) & - & $\mathrm{x}$ & - & - & $(26)$ \\
\hline 2 & Peng et al. (2014) & - & - & $\begin{array}{l}(8) \\
* *\end{array}$ & - & (9) & - & $\mathrm{x}$ & cte & cte & $(15)$ \\
\hline 3 & Boutana et al. (2017a) & - & $\mathrm{x}$ & $(8)$ & - & $(9)$ & $\mathrm{x}$ & $\mathrm{x}$ & $\mathrm{x}$ & - & $\mathrm{x}$ \\
\hline 4 & Chaibi et al. (2018) & - & $(10)$ & - & - & - & $(18)$ & cte & - & - & experimental \\
\hline 5 & Cibira and Koscová (2014) & - & $(10)$ & - & - & - & $(18)$ & cte & cte & - & - \\
\hline 6 & Lineykin et al. (2014) & - & $\begin{array}{c}(10) \\
*\end{array}$ & - & - & - & (19) & cte & $1<\mathrm{a}<2$ & - & - \\
\hline 7 & Mahmoud and Xiao (2013) & - & $(10)$ & - & - & $(7)$ & - & $\mathrm{x}$ & - & - & - \\
\hline 8 & Ishaque et al. (2011b) & - & $(10)$ & - & - & $(7)$ & - & $\mathrm{x}$ & cte & - & - \\
\hline 9 & Jaimes and Sousa (2017) & & & & & & $\mathrm{x}$ & & & & \\
\hline 10 & Mares et al. (2015) & & & & & & $\mathrm{x}$ & & & & \\
\hline
\end{tabular}

- : the relation is implicit according to the others relations established;

$\mathrm{x}$ : This parameter it is not used in the model

$$
* \mu_{I_{p v}, \text { new }}=\frac{\mu_{I p v}}{I_{p v, r e f}} \quad * * \mu_{I_{p v}, \text { new }}=\frac{G}{G_{\text {ref }}} \mu_{I_{p v}}
$$

Table 6. General ranking of the equivalent models for PV cell.

\begin{tabular}{cccccc}
\hline Paper & $\begin{array}{c}\text { Error } \\
\text { analysis }\end{array}$ & $\begin{array}{c}\text { Operation } \\
\text { conditions }\end{array}$ & $\begin{array}{c}P V \\
\text { technology }\end{array}$ & $\begin{array}{c}\text { Translation } \\
\text { equations }\end{array}$ & Final \\
\hline Boutana et al. (2017a) & 1 & 5 & 1 & 3 & 7 \\
Mahmoud and Xiao (2013) & 1 & 6 & 3 & 1 & $\mathbf{1}$ \\
Orioli and Gangi (2013) & 1 & 4 & 2 & 8 & $\mathbf{1}$ \\
Ishaque et al. (2011b) & 1 & 1 & 7 & 4 & $\mathbf{1}$ \\
Chaibi et al. (2018) & 2 & 2 & 8 & 2 & $\mathbf{2}$ \\
Peng et al. (2014) & 2 & 7 & 9 & 9 & $\mathbf{2}$ \\
Jaimes and Sousa (2017) & 3 & 10 & 10 & $\mathbf{3}$ \\
Mares et al. (2015) & 2 & 9 & 6 & 5 & $\mathbf{3}$ \\
Cibira and Koscová (2014) & 3 & 8 & 3 & 6 & $\mathbf{3}$ \\
Lineykin et al. (2014) & 3 & & & 3 & $\mathbf{3}$ \\
\hline
\end{tabular}

\section{CONCLUSIONS}

PV cell equivalent model parameter estimation problem is a hot research topic in renewable energy. In this paper, the existing research works on PV cell model parameter estimation problem are classified per number of parameters, parameters' extraction, translation equations and PV technology. The existent models were discussed pointing out its different levels of approximation.

According to the qualitatively comparison in terms of PV technology, operation conditions, translation equations, and assumptions and timeconsuming level performed in this work, four models were classified as the most appropriate to be used to emulate the solar cell behaviour: Boutana et al. (2017a), Mahmoud and Xiao (2013), Orioli and Di Gangi (2013) and Ishaque (2011b).
The error analysis is considered the most important issue; however, it was observed it is often not complete or properly evaluated. It is suggested that this investigation should be like that performed by Boutana et al. (2017a) and Mahmoud and Xiao (2013) that presented graphically the error at all curve I-V, or at least, as was done by Ishaque et al. (2011b) that computed the error to each different condition. Since it was observed that the most recent is not necessarily the best one, it is indispensable the comparison to other existent models, mainly the ones appointed here as Group 1, and under the same conditions that the first one was developed.

There are few different operation conditions and there are also a few PV technologies considered in almost all PV models which limits its accuracy. Some PV modules can be used to overcome these limitations, such as: KC 200GT, S36, SW255, SQ150PC, SP-70, SM 55 and ST40. It is also advised the use 
of experimental data to guarantee the effectiveness of the model when both temperature and radiation are acting at different ranges simultaneously. The implementation of more data improves the capacity of energy production's prediction which is more adequate than using direct expressions that relate just the efficiency of the PV cells to ambient conditions, since it is not possible to describe the entire I-V curve, fundamental to design the power plant.

Translation equations should be chosen carefully, some models used expressions already considered outdated. Parameters such as ideality factor presents lack of clearness, it is necessary detailed study to related it to PV technologies. The direct relation between ideality factor and the PV technology deserves special attention in future research.

\section{ACKNOWLEDGEMENTS}

The authors are thankful to the Federal University of Rio Grande do Norte (UFRN), Department of Mechanical Engineering and School of Sciences and Technology, Natal Campus, for providing the necessary facilities for the preparation of the paper. The research was financially supported by the Coordination for the Improvement of Higher Education Personnel (CAPES), through the mechanical engineering post-graduation course UFRN/PPGEM (\#23001011009P2).

\section{RESPONSIBILITY NOTICE}

The authors are the only responsible for the online/printed material included in this work.

\section{REFERENCES}

Akbaba M, Alattawi MAA. A new model for I$\mathrm{V}$ characteristic of solar cell generators and its applications. Sol Energy Mater Sol Cells 1995; 37:123-32.

Akhsassi M, El Fathi A, Erraissi N, Aarich N, Bennouna A, Raoufi $M$, et al.. Experimental investigation and modeling of the thermal behavior of a solar PV module. Sol Energy Mater Sol Cells 2018; 180:271-9.

Almonacid F., Fernández EF, Rodrigo P, PérezHigueras PJ, Rus-Casas C. Maximum power of a High Concentrator Photovoltaic (HCPV) module using an artificial neural network. Energy 2013; 53:165-72.

AlRashidi MR, AlHajri MF, El-Naggar KM, AlOthman AK. A new estimation approach for determining the I-V characteristics of solar cells. Sol. Energy 2011; 85:1543-50.

Altındal S, Tataroglu A, Dokme I, 2005. Density of interface states, excess capacitance and series resistance in the metal-insulator- semiconductor (MIS) solar cells. Sol. Energy Mater. Sol. Cells 2005; 85(3):345-58.
Al-Waelia A. H.A., K. Sopiana, Jabar H. Yousifb, Hussein A. Kazemb, John Boland, Miqdam T. Chaichan. Artificial neural network modeling and analysis of photovoltaic/thermal system based on the experimental study. Energy Convers. Manage. 2019; 186: $368-379$.

Araki $\mathrm{K}$ and Yamaguchi M. Novel equivalent circuit model and statistical analysis in parameters identification. Sol. Energy Mater. Sol. Cells 2003; 75:457-66.

Araujo GL, Sanchez E. Analytical expressions for the determination of the maximum power point and the fill factor of a solar cell. Sol. Cells 1982; 5:37786.

Askarzadeh A, Rezazadeh A. Artificial bee swarm optimization algorithm for parameters identification of solar cell models. Appl Energy 2013; 102:943-9.

Ayop R, Tan C W. A comprehensive review on photovoltaic emulator. Renew Sustain Energy Rev 2017; 80:430-52.

Bai J, Liu S, Hao Y, Zhang Z, Jiang M, Zhang Y. Development of a new com- pound method to extract the five parameters of PV modules. Energy Convers Manag 2014; 79:294-303.

Bail M, Schulz M, Brendel R. Space charge region-dominated steady-state photoconductance in low-lifetime Si wafers. Appl Phys Lett 2003; 82:7579.

Barukcic M, Hederic Z, Spoljaric Z. The estimation of $\mathrm{I}-\mathrm{V}$ curves of $\mathrm{PV}$ panel using manufacturers' I-V curves and evolutionary strategy. Energy Convers Manage 2014; 88:447-58.

Bätzner DL, Romeo A, Zogg H, Tiwari AN. $\mathrm{CdTe} / \mathrm{CdS}$ solar cell performance under low irradiance. In: 17th EC PV Solar Energy Conference, Munich, Germany, October 22-26, 200: VB 1.40.

Bianchini A, Gambuti M, Pellegrini M, Saccani C. Performance analysis and economic assessment of different photovoltaic technologies based on experimental measurements. Renew Energy 2016; 85:1-11.

Boer EWI, Jochemsen M, Klapwijk TM, Morpurgo AF, Niemax J, Tripathi AK, et al. Space charge limited transport and time of flight measurements in tetracene single crystals: A comparative study. Appl. Phys. 2004; 95:1196.

Boutana N, Mellit A, Haddada S, Rabhi A, Massi Pavan A. An explicit I-V model for photovoltaic module technologies. Energy Convers Manage 2017; 138:400-12.

Bouzidi K, Chegaar M, Bouhemadou A. Solar cells parameters evaluation considering the series and shunt resistance. Sol. Energy Mater. Sol. Cells 2007; 91(18):1647-51.

Brus, VV. On quantum efficiency of nonideal solar cells. Sol. Energy 2012; 86: 786-91.

Caracciolo F, Dallago E, Finarelli DG, Liberale A, Merhej P. Single-variable optimization method for 
evaluating solar cell and solar module parameters. Photovolt IEEE J 2012; 2:173-80.

Carrero C, Amador J, Arnaltes S. A single procedure for helping PV designers to select silicon PV modules and evaluate the loss resistances. Renew Energy 2007; 32:2579-89.

Chaibi Y, Salhia M, El-jounib A, Essadkic A. A new method to extract the equivalent circuit parameters of a photovoltaic panel. Sol. Energy 2018; 163, 376-86.

Chan D, Phillips J, Phang J. A comparative study of extraction methods for solar cell model parameters. Solid-State Electron 1986; 29:329-37.

Chan, D.S.H., Phang, JCH. Analytical methods for the extraction of solar-cell single- and doublediode model parameters from I-V characteristics. IEEE Trans. Electron Dev 1987; 34:286-93.

Charles JP, Abdelkrim M, Muoy YH, Mialhe P. A practical method of analysis of the current-voltage characteristics of solar cells. Sol. Cells 1981; 4(2):169-78.

Chatterjee A, Keyhani A, Kapoor D. Identification of photovoltaic source models. IEEE Trans. Energy Convers. 2011; 26:883-9.

Chegaar M, Nehaoua N, Bouhemadou A. Organic and inorganic solar cells parameters evaluation from single I-V plot. Energy Convers Manage 2008; 49(6):1376-9.

Chenni R, Makhlouf M, Kerbache T, Bouzid A. A detailed modeling method for photovoltaic cells. Energy 2007; 32:1724-30.

Chih-Tang S, Noyce, RN, William S. Carrier generation and recombination in $\mathrm{P}-\mathrm{N}$ junctions and $\mathrm{P}-$ $\mathrm{N}$ junction characteristics. Proceedings of the IRE; 1957; 45(9):1228-43.

Chin VJ, Salam Z, Ishaque K. Cell modelling and model parameters estimation techniques for photovoltaic simulator application: a review. Appl Energy 2015; 154:500-19.

Cibira G, Koscová M. Photovoltaic module parameters acquisition model. Appl Surface Science journal 2014; 312:74-80.

Ciulla G, Lo Brano V, Di Dio V, Cipriani G. A comparison of different one-diode models for the representation of I-V characteristic of a PV cell. Renew Sustain Energy Rev 2014; 32:684-96.

Cotfas DT, Cotfas PA, Kaplanis S. Methods to determine the dc parameters of solar cells: a critical review. Renew Sustain Energy Rev 2013; 28:588-96.

Cuce E, Cuce PM, Karakas IH, Bali T. An accurate model for photovoltaic (PV) modules to determine electrical characteristics and thermodynamic performance parameters. Energy Convers Manage 2017, 146:205-16.

Cuce E, Cuce PM, Wood CJ, Riffat SB. Toward aerogel based thermal superinsulation in buildings: a comprehensive review. Renew Sustain Energy Rev 2014a; 34:273-99.

Cuce E, Young CH, Riffat SB. Performance investigation of heat insulation solar glass for low- carbon buildings. Energy Convers Manage 2014b; 88:834-41.

Cuce E, Young $\mathrm{CH}$, Riffat SB. Thermal insulation, power generation, lighting and energy saving performance of heat insulation solar glass as a curtain wall application in Taiwan: a comparative experimental study. Energy Convers Manage 2015; 96:31-8.

Das AK. An explicit J-V model of a solar cell for simple fill factor calculation. Solar Energy 2011; 85:1906-9.

Das AK. Analytical derivation of explicit J-V model of a solar cell from physics based on implicit model. Solar Energy 2012; 86: 26-30.

Das N, Wongsodihardjo H, Islam S. Modeling of multi-junction photovoltaic cell using MATLAB/Simulink to improve the conversion efficiency. Renew Energy 2015; 74:917-24.

De Blas MA, Torres JL, Prieto E, and García A. Selecting a suitable model for characterizing photovoltaic devices. Renewable Energy 2002; 25:371-80.

De Soto W, Klein SA, Beckman WA. Improvement and validation of a model for photovoltaic array performance. Solar Energy 2006; 80(1); 78-88.

Di Piazza MC, Luna M, Vitale G. Dynamic PV model parameter identification by least-squares regression. Photovolt IEEE J 2013; 3:799-806.

Du H, Champness $\mathrm{CH}$, Shih I. Results on monocrystalline CuInSe 2 solar cells. Thin Solid Films 2005; 480/481(1):37-41.

Easwarakhanthan T, Bottin J, Bouhouch I, Boutrit C. Renew. Energy 1986: 1-12.

Ebong A, Upadhyaya V, Rounsaville B, Kim DS, Tate K, Rohatgi A. 18\% Large area screen-printed solar cells on textured MCZ silicon with high sheet resistance emitter. In: Conf. Record of the 2006 IEEE 4th World Conf. on Photovoltaic Energy Conversion, 2006; 2:1326-9.

El-Nahass MM, Zeyada HM, Aziz MS, and ElGhamaz NA. Carrier transport mechanisms and photovoltaic properties of $\mathrm{Au} / \mathrm{p}-\mathrm{ZnPc} / \mathrm{p}-\mathrm{Si}$ solar cell. Solid-State Electron 2005; 49(8):1314-19.

Eppler AM, Ballard IM, and Nelson J. Charge transport in porous nanocrystalline titanium dioxide. Physica E 2002; 14:197-202.

Faiman D. Assessing the outdoor operating temperature of photovoltaic modules. Prog. Photovolt. Res. Appl. 2008; 16:307-315.

Farivar G, Asaei B. Photovoltaic module single diode model parameters extraction based on manufacturer datasheet parameters. In: proceedings of IEEE international conference on Power and energy (PE Con 2010). IEEE; 2010. p. 929-34.

Fathabadi H. Novel neural-analytical method for determining silicon/plastic solar cells and modules characteristics. Energy Convers Manag 2013; 76:2539. 
Feng L, Zhang J, Li B, Cai W, Cai Y, Wu L, et al.. The electrical, optical properties of CdTe polycrystalline thin films deposited under $\mathrm{Ar}-\mathrm{O} 2$ mixture atmosphere by close spaced sublimation. Thin Solid Films 2005; 491(1/2):104-9.

Fouad MM, Shihatab LA, Morgana EI. An integrated review of factors influencing the performance of photovoltaic panels. Renew Energy 2017; 10:1499-511.

Gadeo-Martos M. A., Yuste-Delgado A. J., Cruz F. A., Fernandez-Prieto J.A., Canada-Bago J. Modeling a High Concentrator Photovoltaic Module

Gianoli-Rossi E, Krebs K. Energy rating of PV modules by outdoor response analysis, 8th E.C. PV Solar Energy Conference 1988, Florence, Italy.

Goldenblum A, Pintilie I, Buda M, Popa A, Botila T, Dimoulas A, et al. Space-charge-limited current involving carrier injection into impurity bands of high-k insulators. Appl. Phys. Lett. 2005; 86:203506.

Goradia C, Thesling W. Key Factors Limiting the Open Circuit Voltage of $n+p p+$ Indium Phosphide Solar Cells. IEEE 1990; 90:386-93.

Gow, JA, Manning, CD. Development of a photovoltaic array model for use in power-electronics simulation studies. IEE Proceedings: Electric Power Applications 1999; 146(2):193-200.

Green M. Solar cell fill factors: general graph and empirical expressions. Solid State Electron 1981; 24:788-9.

Green Technology. The Solar Singularity is Nigh, http://www.greentechmedia.com/articles; 2015. [accessed 13 march 2018]

Gupta S, Tiwari H, Fozdar M, Chandna V. Development of a two-diode model for photovoltaic modules suitable for use in simulation studies. In: proceedings of Asia-Pacific power and energy engineering conference (APPEEC 2012) IEEE; 2012: $1-4$.

Hadj Arab A, Chenlo F, Benghanem M. Loss-ofload probability of photovoltaic water pumping systems. Sol. Energy 2004; 76:713-23.

Hansen C. Parameter Estimation for Single Diode Models of Photovoltaic Modules, Sandia National Laboratories, Albuquerque, NM, Forthcoming; 2015.

Hansen CW, Luketa-Hanlin A, Stein JS Sensitivity of single diode models for photovoltaic modules to method used for parameter estimation; 2013.

Huld T, Friesen G, Skoczek A, Kenny RP, Sample T, Field M, Dunlop ED. A power-rating model for crystalline silicon photovoltaic modules. Sol. Energy Mater. Sol. Cells 2011; 95:3359-69.

Hyvarinen J, Karila J. New analysis method for crystalline silicon cells. In: 3rd World Conf. Photovoltaic Energy Convers. 2003; 2:1521-24. ISBN 4-9901816-0-3.

International Electrotechnical Commission 2005. IEC 61215 Ed. 2.0 (English 2005). Crystalline silicon terrestrial photovoltaic (PV) modules - Design qualification and type approval. Ed. 2.0.

Ishaque K, Salam Z, Syafaruddin, A comprehensive MATLAB Simulink PV system simulator with partial shading capability based on twodiode model, Sol. Energy 2011a; 85:2217-27.

Ishaque K, Salam Z, Taheri H. Simple, fast and accurate two-diode model for photovoltaic modules. Sol Energy Mater Sol Cells 2011b, 95:586-94.

Jaimes AF, Sousa FR. Simple modeling of photovoltaic solar cells for indoor harvesting applications. Sol. Energy 2017; 157:792-802.

Jain SC, Aernout T, Kapoor AK, Kumar V, Geens W, Poortmans J, et al.. I-V characteristics of dark and illuminated PPV-PCBM blends solar cells. Synth. Met. 2005; 148(3): 245-50.

Jordehi AR. Parameter estimation of solar photovoltaic (PV) cells: A review. Renew Sustain Energy Rev 2016; 61: 354-71.

Karmalkar S, Haneefa S. A physically based explicit J-V model of a solar cell for simple design calculations. IEEE Electron Device Lett. 2008; 29(5):449-51.

Karmalkar S, Haneefa S. The power law J-V model of an illuminated solar cell. Sol. Energy Mater. Sol. Cells 2011; 95:1076-84.

Khan F, Baek SH, Kim JH. Wide range temperature dependence of analytical photovoltaic cell parameters for silicon solar cells under high illumination conditions. Appl Energy 2016; 183:71524.

Khan F, Baek SH, Park Y, Kim JH. Extraction of diode parameters of silicon solar cells under high illumination conditions. Energy Converse Manage 2013; 76:421-9.

Khan F, Singh SN, Husain M. Determination of the diode parameters of a-Si and CdTe solar modules using variation of the intensity of illumination: an application. Sol. Energy 2011; 85:2288-94.

Khan F. Fabrication of diffused junction crystalline silicon solar cells with texturization and different antireflection coatings and study of their photovoltaic properties, New Delhi; 2012.

Kippelen B, Bredas JL. Organic photovoltaics. Energy Environ Sci 2009; 2:251-61.

Klaer J, Bruns J Henninger R Siemer K, Klenk $\mathrm{R}$, Ellmer K, et al. Efficient $\mathrm{CuInS}_{2}$ thin-film solar cells prepared by a sequential process. Semicond. Sci. Technol 1998; 13:1456-8.

Kou Q, Klein SA, Beckman WA. A method for estimating the long-term performance of directcoupled PV pumping systems. Solar Energy 1998; 64:33-40.

Kumar G, Panchal AK. A non-iterative technique for determination of solar cell parameters from the light generated IV characteristic. J Appl Phys 2013; 114:084904

Kurnik J, Jankovec M, Brecl K, Topic M. Outdoor testing of PV module temperature and performance under different mounting and operational 
conditions. Sol. Energy Mater. Sol. Cells 2011, 95:373-376.

Kurobe K, Matsunami H. New two-diode model for detailed analysis of multicrystalline silicon solar cells. Jpn J Appl Phys 2005; 44:8314.

Kwak JI, Nam SH, Kim L, An Y. Potential environmental risk of solar cells: Current knowledge and future challenges Journal of Hazardous Materials 2020; 392:122297.

Laarabi B., May Tzuc O., Dahlioui D., Bassam A., Flota-Banuelos M., Barhdadi A. Artificial neural network modeling and sensitivity analysis for soiling effects on photovoltaic panels in Morocco. Superlattices and Microstructures 2019; 127: 139-150.

Lasnier F and Ang TG, Photovoltaic Engineering Handbook. New York: Adam Hilger, 1990.

Lim LHI, Ye Z, Ye J, Yang D, Du H. A linear method to extract diode model parameters of solar panels from a single I-V curve. Renew Energy 2015; 76:135-42.

Lineykin S, Averbukhb M, Kuperman A. An improved approach to extract the single-diode equivalent circuit parameters of a photovoltaic cell/panel. Renew Sustain Energy Rev 2014; 30: 282 289.

Lipinski M, Panek P, Ciach R. The industrial technology of crystalline silicon solar cells. J. Optoelectron. Adv. Mater. 2003; 5(5):1365-71. Availability:

https://joam.inoe.ro/arhiva/pdf5_5/Lipinski.pdf.

Lo Brano V, Orioli A, Ciulla G, Di Gangi A. An improved five-parameter model for photovoltaic module. Sol Energy Mater Sol Cells 2010; 94:135870 .

Lo Brano V, Orioli A, Ciulla G. On the experimental validation of an improved fiveparameter model for silicon photovoltaic modules. Sol Energy Mat Sol C 2012; 105:27-39.

Lorenzo, E. Solar electricity. Engineering of Photovoltaic Systems. Spain: Progensa; 2009. p. 93106.

Lumb MP, Bailey CG, Adams JG, Hillier G, Tuminello F, Elarde VC, et al. Analytical driftdiffusion modeling of GaAs solar cells incorporating a back mirror. In: 39th photovoltaic specialists conference. IEEE 2013:1063-8.

Lun SX, Du CJ, Yang GH, Wang S, Guo TT, Sang, JS, et al. An explicit approximate I-V characteristic model of a solar cell based on padé approximants. Sol. Energy 2013; 92(6):147-59.

Mahmoud YA, Xiao W. A parameterization approach for enhancing PV model accuracy. Trans Ind Electron IEEE 2013; 60:5708-16.

Mares, O., Paulescu, M., Badescu, V., 2015. A simple but accurate procedure for solving the fiveparameter model. Energy Convers. Manage. 105, 13948.

Marsal LF, Martin I, Pallarès J, Orpella A, and Alcubilla R. Annealing effects on the conduction mechanisms of $\mathrm{p}+$-amorphous- $\quad \mathrm{Si}_{0.8} \mathrm{C}_{0.2}: \mathrm{H} / \mathrm{n}$ crystalline-Si diodes. Appl. Phys. 2003; 94: 2622.

Mazhari B. An improved solar cell circuit model for organic solar cells. Sol Energy Mater Sol Cells 2006; 90:1021-33.

Mellit A, Saglam S, Kalogirou SA. Artificial Neural Network- based model for estimating the produced power of a photovoltaic module. Renew. Energy 2013; 60:71-8.

Mellit, A, Pavan, AM. Performance prediction of $20 \mathrm{kWp}$ grid-connected photovoltaic plant at Trieste (Italy) using artificial neural network. Energy Convers. Manage. 2010: 51:2431-41.

Menicucci D, Fernandez JP. User's manual for PVFORM: a photovoltaic system simulation program for stand-alone and grid interactive applications. Sandia National Laboratories, Albuquerque, USA, 1998.

Mermoud A. Pvsyst: Software for the Study and Simulation of Photovoltaic Systems 2012. ISE, University of Geneva. <www.pvsyst.com>.

Nelson J. The physics of solar cells. 1th ed. Singapore: Imperial College Press; 2003.

Nishioka K, Sakitani N, Kurobe K, Yamamoto Y, Ishikawa Y, Uraoka Y, et al. Analysis of the temperature characteristics in polycrystalline si solar cells using modified equivalent circuit model. Jpn. J. Appl. Phys. 2003; 42(12): 7175-9.

Nishioka K, Sakitani N, Uraoka Y, Fuyuki T. Analysis of multicrystalline silicon solar cells by modified 3-diode equivalent circuit model taking leakage current through periphery into consideration. Sol Energy Mater Sol Cells 2007; 91:1222-7.

Orioli A, Di Gangi A. A procedure to calculate the five-parameter model of crystalline silicon photovoltaic modules on the basis of the tabular performance data. Appl Energy 2013; 102:1160-77.

Ortiz-Conde A, Sánchez FJG, Muci J. New method to extract the model parameters of solar cells from the explicit analytic solutions of their illuminated I-V characteristics. Sol Energy Mater Sol Cells 2006; 90:352-61.

Oukili M, Zouggar S, Seddik M, Ouchbel T. Comparative study of the moroccan power grid reliability in presence of photovoltaic and wind generation. Energy Procedia 2013; 4:366-377.

Pallarès J, Cabré R, and Marsal LF. A compact equivalent circuit for the dark current-voltage characteristics of non-ideal solar cells. J Appl Phys 2006; 100:84513.

Pavan AM, Mellit A, Lughi V, Explicit empirical model for general photovoltaic devices: experimental validation at maximum power point. Sol. Cells 2014; 101:105-116.

Peng L, Sun Y, Meng Z. An improved model and parameters extraction for photovoltaic cells using only three state points at standard test condition. J Power Sour 2014; 248:621-31. 
Phang J, Chan D, Phillips J. Accurate analytical method for the extraction of solar cell model parameters. Electron. Lett. 1984; 20:406-8.

Piliougine M, Elizondo D, Mora $\square$ López L, Sidrach $\square$ de $\square$ Cardona M. Modelling photovoltaic modules with neural networks using angle of incidence and clearness index. Prog Photovolt: Res App 2015; 23:513-23.

Radziemska E, Klugmann E. Thermally affected parameters of the current-voltage characteristics of silicon photocell. Energy Convers Mgmt 2002; 43:1889.

Radziemska E. Thermal performance of Si and GaAs based solar cells and modules: a review. Prog. Energy Combust. Sci. 2003; 29(5):407-24.

Rahman MM, Hasanuzzamana M, Rahim NA. Effects of various parameters on PV-module power and efficiency. Renew Sustain Energy Rev 2015; 103: 348-58.

Ram JP, Babu TS, Rajasekar N. A comprehensive review on solar PV maximum power point tracking techniques. Renew Sustain Energy Rev 2017; 67: 826-47.

Ramanujam, J., Verma, A., González-Díaz, B. Guerrero-Lemus, R., del Cañizo, C., GarcíaTabarés, E., Rey-Stolle, I., Granek, F., Korte, L., Tucci, M., Rath, J., Singh, U.P., Todorov, T., Gunawan, O., Rubio, S., Plaza, J.L., Diéguez, E., Hoffmann, B., Christiansen, S., Cirlin, G.E., 2016. Inorganic photovoltaics - planar and nanostructured devices. Prog. Mater. Sci. 82, 294-404.

Rawat R, Lamba R, Kaushik SC. Thermodynamic study of solar photovoltaic energy conversion: An overview. Renew Sustain Energy Rev 2017; 71:630-8.

Riffat SB, Cuce E. A review on hybrid photovoltaic/thermal collectors and systems. Int $\mathrm{J}$ Low-Carbon Technol 2011; 6(3):212-41.

Rosales-Quintero P, Torres-Jacome A, MurphyArteaga R, and Landa-Vázquez M. Electrical characterization of n-type a-SiGe: H/p-type crystalline-silicon heterojunctions. Semicond. Sci. Technol. 2004; 19:366-372.

Rose A. Space-Charge-Limited Currents in Solids. Phys. Rev. 1955; 97:1538.

Ruschel C.S., Gasparin F.P., Costa E.R., Krenzinger A. Assessment of PV modules shunt resistance dependence on solar irradiance, Sol Energy 2016. 133:35-43.

Sah CT. Fundamentals of solid-state electronics. Singapore: World Scientific; 1991.

Salam Z, Ishaque K, Taheri H. An improved twodiode photovoltaic (PV) model for PV system. In: Joint international conference on power electronics, drives and energy systems (PEDES) \& 2010 Power India, 2010: 1-5.

Saloux E, Teyssedou A, Mikhail S. Explicit model of photovoltaic panels to determine voltage and currents at the maximum power point. Sol. Energy $2011 ; 85: 713-22$.
Sampaio PGV, González, MOA, Photovoltaic solar energy: Conceptual framework, Renew Sustain Energy Rev 2017; 74:590-601.

Schauer F. Space-charge-limited currents for organic solar cells optimisation. Sol. Energy Mater. Sol. Cells 2005; 87:235-250.

Schwingshackl C, Petitta M, Wagner JE, Belluardo G, Moser D, Castelli M, et al.. Wind effect on PV module temperature: analysis of different techniques for an accurate estimation. Energy Procedia 2013; 40:77-86.

Sera D, Teodorescu R, Rodriguez P. PV panel model based on datasheet values. In: IEEE International Symposium on Industrial Electronics, Vigo, Spain.; 2007.

Shah S, Tripathy S, Thirumavalavan M, Kalghatgi AT, Krupanidhi SB. Device Processing and I-V Parameter Extraction of MOCVD Grown GaAs/Ge Hetero-Structure Solar Cells, Presented at the Int. Workshop Physics Semiconductor Devices. 2003.

Singh S, Singh M, Kaushik SC. Feasibility study of an islanded microgrid in rural area consisting of $\mathrm{PV}$, wind, biomass and battery energy storage system. Energy Convers Manage 2016; 128:178-90.Slimani MEA, Amirat M, Kurucz I, Bahria S, Hamidat A, Chaouch WB. A detailed thermal-electrical model of three photovoltaic/thermal (PV/T) hybrid air collectors and photovoltaic (PV) module: comparative study under Algiers climatic conditions. Energy Convers Manage 2017; 133:458-76.

Sites JR, Tavakolian H, Sasala RA. Analysis of apparent quantum efficiency. Sol. Cells 1990; 29:3948.

Soon JJ, Low K-S, Goh ST. Multi-dimension diode photovoltaic (PV) model for different PV cell technologies. In: IEEE 23rd International symposium on industrial electronics (ISIE 2014). 2014; 2496 501.

Sudhakar BT, Prasanth RJ, Sangeetha K, Laudani A, Rajasekar N. Parameter extraction of two diode solar PV model using Fireworks algorithm. Sol. Energy 2016; 140:265-76.

Sundareswaran K, Sankar P, Nayak P, Simon SP, Palani S. Enhanced energy output from a PV system under partial shaded conditions through artificial bee colony. Sustain Energy IEEE Trans 2015; 6:198-209.

Suskis P, Galkin I. Enhanced photovoltaic panel model for MATLAB-simulink environment considering solar cell junction capacitance. In: 39th Annual Conf. IEEE Ind Elect. Society (IECON 2013). IEEE; 2013; 1613-18.

Tan JH and Anderson WA. Current transport in copper indium gallium diselenide solar cells comparing mesa diodes to the full cell. Sol. Energy Mater. Sol. Cells 2003; 77:283-92.

Tonui JK, Tripanagnostopoulos Y, Air-cooled $\mathrm{PV} / \mathrm{T}$ solar collectors with low cost performance improvements, Sol. Energy 81 (2007) 498-511. 
Torani K, Rausser G, Zilberman D. Innovation subsidies versus consumer subsidies: a real options analysis of solar energy. Energy Policy 2016; 92:25569.

Tuttle JR, Contreras M, Tennant A, Albin D, Noufi R. High efficiency thin-film $\mathrm{Cu}(\mathrm{In}, \mathrm{Ga}) \mathrm{Se} 2-$ based photovoltaic devices: progress towards a universal approach to absorber fabrication. IEEE 1993; 1:415-21.

University of Manitoba. Energy at the crossroads, http://home.cc.umanitoba.ca/?vsmil/pdf pubs/oecd.pdf; 2017 [accessed 28 march 2018].

Using Fuzzy Rule-Based Systems. Energies. $2019 ; 12: 567$.

Van Dyk EE, Meyer EL. Analysis of the effect of parasitic resistances on the performance of photovoltaic modules. Renew Energy 2004; 29:33344.

Villalva MG, Gazoli JR, Filho ER. Comprehensive approach to modeling and simulation of photovoltaic arrays. IEEE Trans Power Electron 2009; 24:1198-208.

Walker G. Evaluating MPPT converter topologies using a MATLAB PV model. J. Elect. Electron. Eng. Aust. 2001; 21(1):49-55. Availability: https://search.informit.com.au/documentSummary;dn $=537020271845747 ;$ res=IELENG. ISSN: 0725-2986.

Wang G., Su Y., Shu L. One-day-ahead daily power forecasting of photovoltaic systems based on partial functional linear regression models. Renewable Energy 2016; 96: 469-478.

Wolf M, Rauschenbach H. Series resistance effects on solar cell measurements. Adv Energy Convers 1963; 3:455-79.

Xiao W, Dunford WG, and Capel A. A novel modeling method for photovoltaic cells. In: IEEE 35th Annu. Power Electron. Spec. Conf. (PESC), 2004; 3:1950-6.

Yadava A. K., Chandela S.S. Identification of relevant input variables for prediction of 1-minute time-step photovoltaic module power using Artificial Neural Network and Multiple Linear Regression Models Renew Sustain Energy Rev 2017; 77: 955969.

Zaharatos BR, Campanelli M, Tenorio L. On the estimability of the PV single $\square$ diode model parameters. Stat Anal Data Min: ASA Data Sci J 2015.

Zhu J, Dalal VL, Ring MA, Gutierrez JJ, and Cohen JD. Growth and properties of amorphous Ge:H solar cells. J. Non-Cryst. Solids 2004; 338:651-4. 